\title{
Some Notes on the Lugiin Gol, Mushgai Khudag and Bayan Khoshuu Alkaline Complexes, Southern Mongolia
}

\author{
Munkhtsengel Baatar ${ }^{1 *}$, Gerel Ochir ${ }^{1}$, Jindrich Kynicky ${ }^{2}$, Shigeru Iizumi ${ }^{3}$, Piero Comin-Chiaramonti ${ }^{4}$ \\ ${ }^{1}$ Department of Geology, Mongolian University of Science \& Technology, Ulaanbaatar, Mongolia \\ ${ }^{2}$ Department of Geology and Pedology, Mendel University, Brno, Czech Republic \\ ${ }^{3}$ Department of Geosciences, Shimane University, Matsue, Japan \\ ${ }^{4}$ Department of Mathematics and Geosciences, Trieste University, Trieste, Italy \\ Email: *munkhtsengel@yahoo.com
}

Received July 16, 2013; revised August 19, 2013; accepted September 22, 2013

Copyright (C) 2013 Munkhtsengel Baatar et al. This is an open access article distributed under the Creative Commons Attribution License, which permits unrestricted use, distribution, and reproduction in any medium, provided the original work is properly cited.

\begin{abstract}
Volcanic-plutonic alkaline complexes from Lugiin Gol, Mushgai Khudag and Bayan Khoshuu, southern Mongolia (244, 139 and $131 \mathrm{Ma}$, respectively) occur within grabens in E-W lineaments. They are represented by syenitic rock-types (silica undersaturated to slightly silica oversaturated) potassic rocks and are associated to stockworks of carbonatitic veins, dykes and so on. Geochemical characteristics and isotope systematics point to a veined mantle source particularly enriched in LILE and LREE. The carbonatitic veins show high contents of $\mathrm{Ba}, \mathrm{Sr}$, Th and REE and are suitable as potential ore deposits.
\end{abstract}

Keywords: Mongolia; Alkaline Complexes; Carbonatites; REE Deposits

\section{Introduction}

Alkaline province in Southern Mongolia is well known for associated alkaline-carbonatite complexes (e.g. Lugiin Gol, Mushgai Khudag and Bayan Khoshuu) (Figure 1). These complexes and a number of smaller plutons with carbonatite dykes and veins are controlled by E-W faults and formed in continental rift environment. Alkaline and carbonatitic rocks [1-7] outcrop along the northern and south Gobi rift zones (Late Paleozoic to Early-Late Mesozoic aged) and consist mainly of volcanic-plutonic complexes.

We present here a review of the petrological and geochemical features of these alkaline-carbonatite complexes.

\section{Geological Background}

The alkaline complexes in South Mongolia are controlled by large extensional structures (Figure 1) and are related to occurrences of Late Paleozoic-Early Mesozoic (Lugiin Gol) and Late Mesozoic (Mushgai Khudag and Bayan Khoshuu) ages, respectively ([8], and therein references).

\subsection{Lugiin Gol Complex (LGC)}

LGC outcrops at the Southeastern side of the Gobi-Tien

${ }^{*}$ Corresponding author.
Shan fold belt, near the boundary with the Sulinkheer suture zone (Figure 1). Gobi-Tien Shan belt is composed mainly of Late Pre-Cambrian limestones, amphibolites and gneisses with Late Paleozoic granitoids and intermediate volcanics. The Sulinkheer zone is characterized by a Paleozoic ophiolitic complex and by Late Paleozoic sediments, in the southern and in the northern areas, respectively. The eastern Lugiin Gol district $\left(108^{\circ} 20^{\prime} \mathrm{E}\right)$ represents a magmatic arc, indicating that remnant oceanic basin (Sulinkheer Sea) existed between North China and a South Gobi microcontinent until Late Permian $[9,10]$.

Notably, the northern area is mainly underlain by black shales, siltstones and sandstones (i.e. Lugiin Gol Formation), intruded by the LGC complex. A silica undersaturated syenitic stock outcrops in an area of about 12 sq.km, showing subcircular outlines with a diameter of $3.5 \mathrm{~km}$. The stock is composed of nepheline-bearing syenite, nepheline syenite and ijolites (Figure 2), surrounded by hornfels [4,11], fenites and skarns. An alkali-granite dyke, $20 \mathrm{~m}$ thick, crosscuts the Lugiin Gol complex. Moreover, a stockwork with two main types of dykes and veins, i.e. carbonatites and phonolites (and phonolites with tinguaitic texture) intrude the complex (cf. Figure 2). 


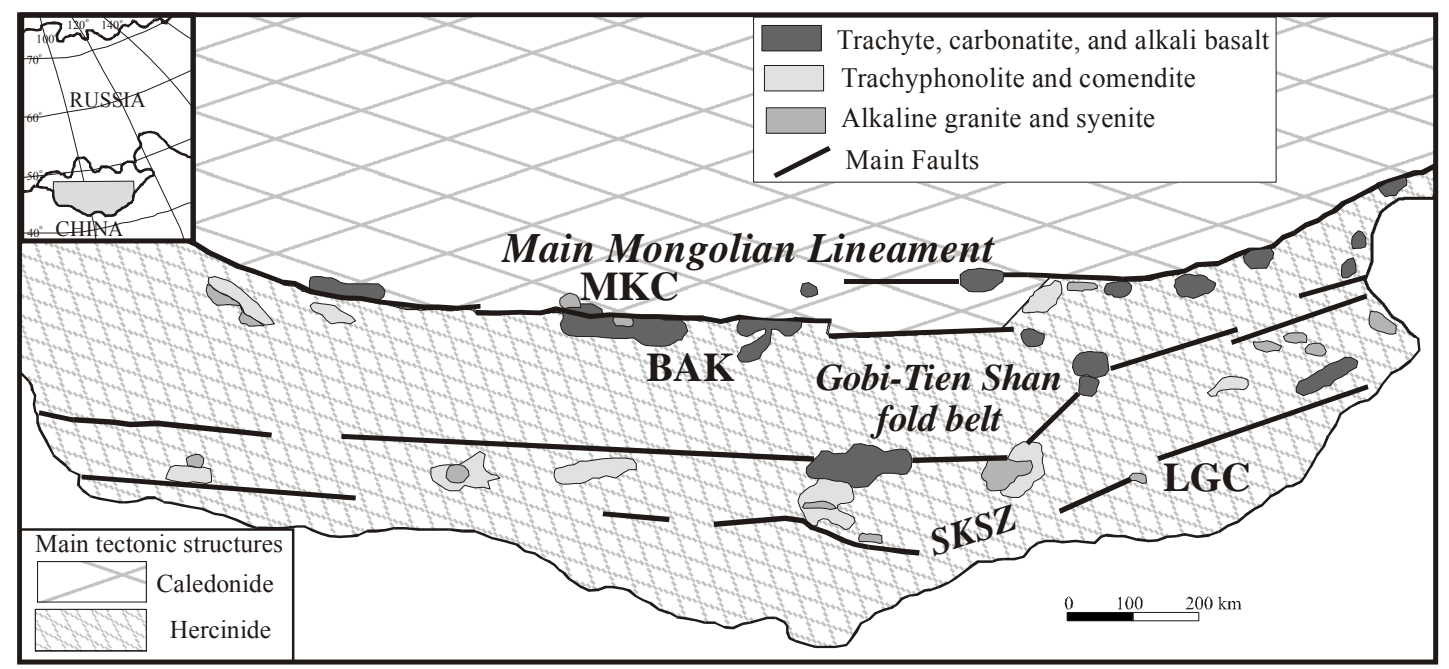

Figure 1. Distribution of alkaline complexes in South Mongolia [3]: MKC, Mushgai Khudag; BAK, Bayan Khoshuu; LGC, Lugiin Gol; SKSZ, Sulinkheer suture zone. Grey field in the inset represents the studied area.

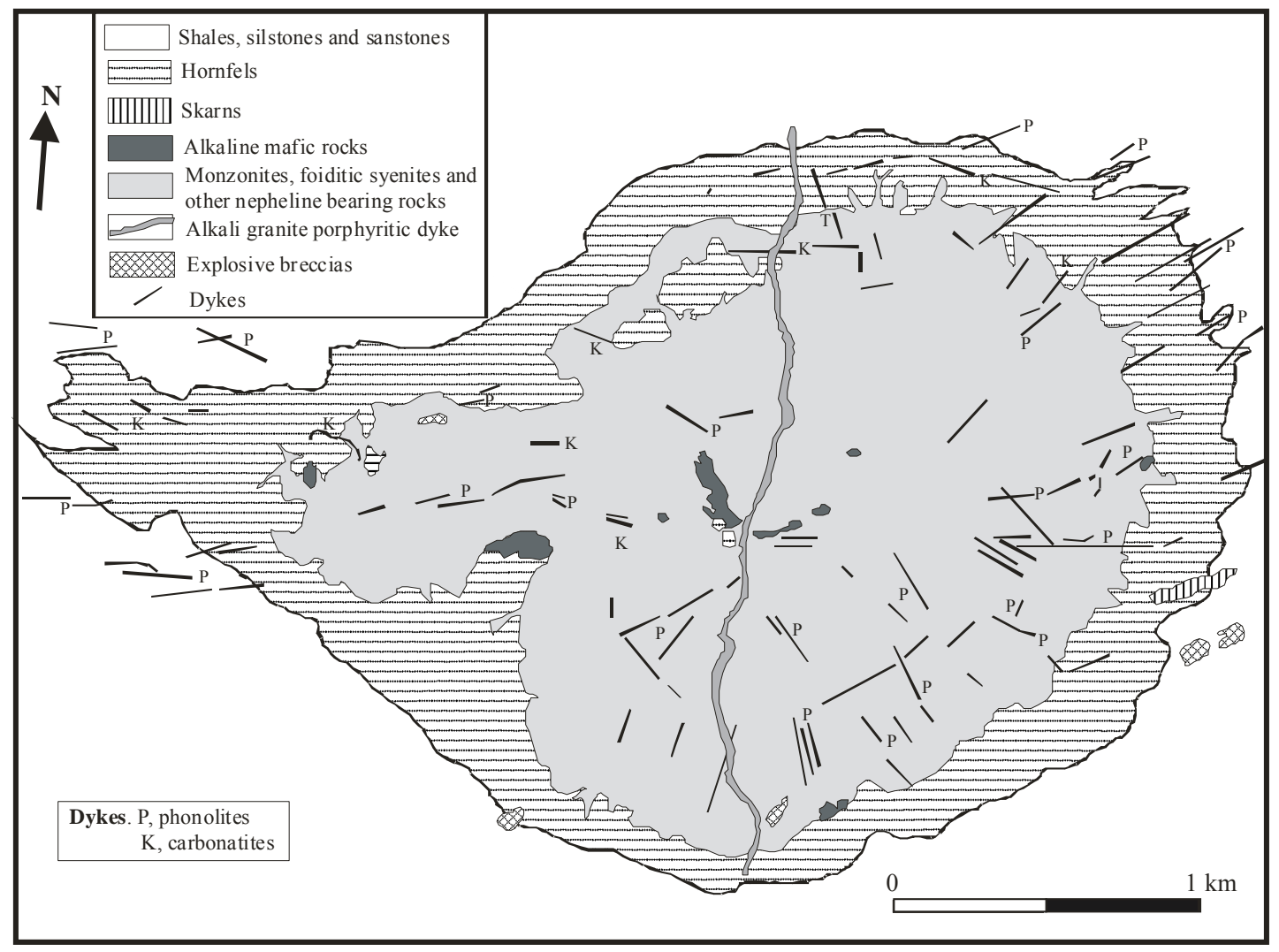

Figure 2. Lithological map of the Lugiin Gol complex [4,12]. Only significant occurrences of carbonatitic dykes and veins are shown.

\subsection{Mushgai Khudag Complex (MKC)}

$\mathrm{MKC}$, along the main Mongolian lineament (Figure 1) consists mainly of stocks and necks of trachytic and syenitic varieties (Figure 3; [13] cut by carbonatitic veins and plugs (F-S-Sr-Ba-REE rich: s. later). Host rocks are represented by Paleozoic sedimentary-volcanic sequences and by Carboniferous granitoids [3]. The K-Ar ages for MKC are between Early Cretaceous (Valanginian) and Late Cretaceous (Cenomanian) times [5].

Genesis of these rocks was interpreted as a result of a mantle plume activity during subduction (Enkhtuvshin, 1995), or, more probably, as rifting related [3]. 


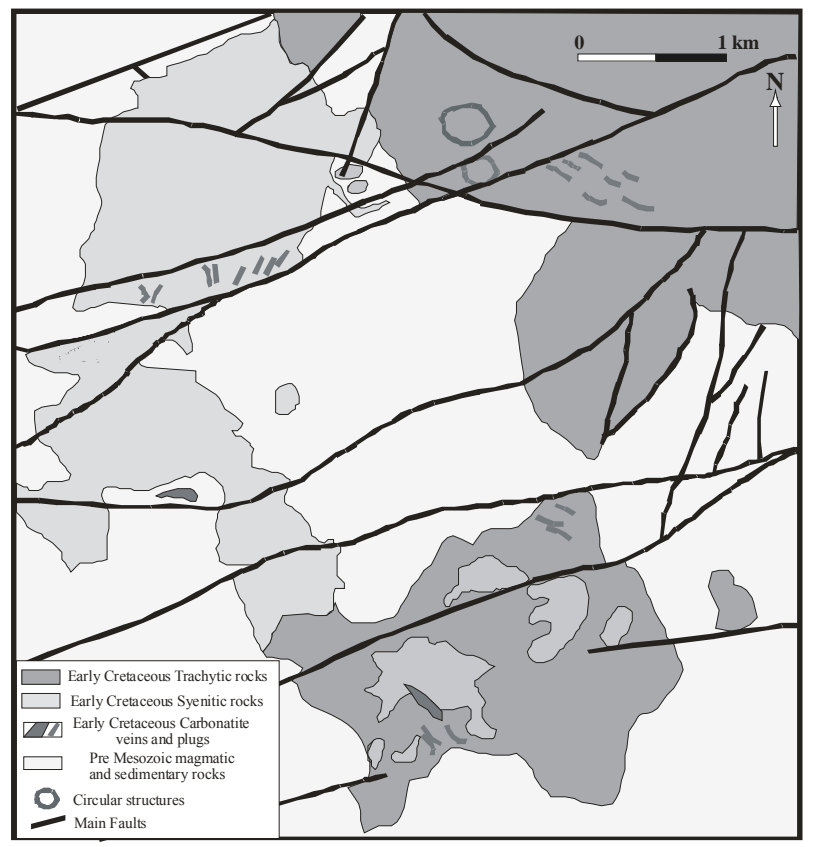

Figure 3. Simplified geological map of the Mushgai Khudag Complex (Latitude: $44^{\circ} 24^{\prime} 3^{\prime \prime} N$, Longitude: $104^{\circ} 3^{\prime} 5^{\prime} \mathrm{E}$ ) after [3].

\subsection{Bayan Khoshuu Complex (BAKC)}

BAKC consists of Late Jurassic to Early Cretaceous trachytes, syenites and monzonites. Late Paleozoic syenites, granites and Silurian volcanic-terrigenous rocks represent host rocks. Syenites and monzonites occur at the core of the complex. Carbonatitic stockworks are noticeable (Figure 4).

Several primary and hydrothermal mineralizations (FS-Sr-Ba-REE rich; cf. [14]) are present mainly as veins intruding the rocks.

\section{Petrographical Outlines}

\subsection{Silicate Rocks}

The petrography is based here above all on the [16] and [17] classifications.

The foid (nepheline) syenites are medium to coarse grained, equigranular to subporphyritic. Major minerals are orthoclase (or $\geq 80$ mole $\%$ ), nepheline, clinopyroxene (usually with augitic-diopsidic core and aegirine-rich rims). Minor minerals are amphibole (arfvedsonite with

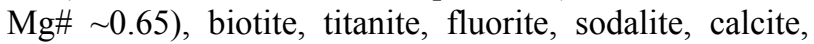
magnetite and apatite. As typical accessory minerals occur zircon, baddeleyite, elpidite, pyrochlore, burbankite, cancrinite and synchysite.

Foid bearing monzonites (syenites) are porphyritic with euhedral phenocrysts of alkali feldspar and plagioclase set in a matrix of clinopyroxene, amphibole, biotite and nepheline: accessory minerals are magnetite, titanite, apatite and zircon.

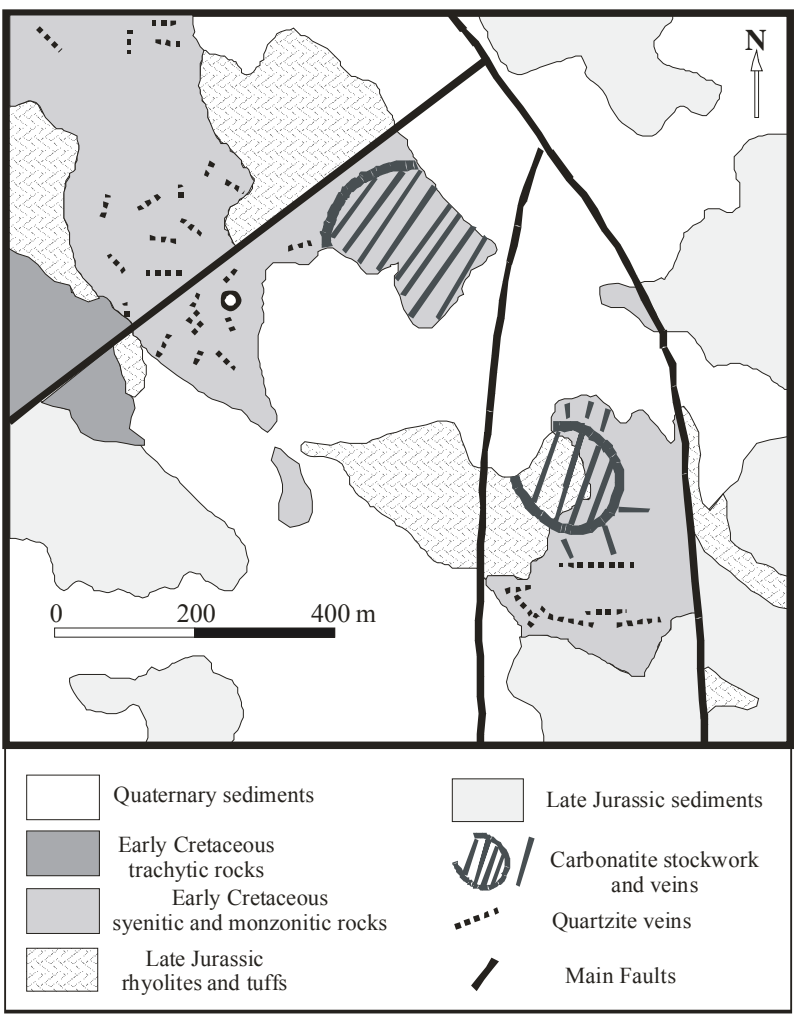

Figure 4. Geological map of the bayan khoshuu complex (modified, after [15]).

Porphyritic fine- to medium-grained K-feldspar monzonites and syenites are composed of $\mathrm{K}$-feldspar, plagioclase, clinopyroxene (augite to diopside $\mathrm{Wo}_{48-37} \mathrm{En}_{40-20} \mathrm{Fs}_{13-21}$ ), alkaline amphibole $(\mathrm{Mg}$ arfvedsonite with $\mathrm{Mg} \mathrm{\# =60-}$ 70), biotite $\left(\mathrm{Ann}_{0.6-0.76}\right)$, magnetite, quartz, plagioclase and accessory apatite, titanite and fluorite.

Phonolites with tinguaitic texture (Tinguaites, i.e. "intrusive phonolites") are usually porphyritic, with phenocrystals of alkali feldspar, nepheline, biotite and aegirine-augite \pm sodic amphibole, being titanite and aegirine the most common inclusions. The groundmass is a fine aggregate of nepheline, alkali feldspar, biotite, aegirine, titanite, apatite, magnetite and zircon. Notably, needles of aegirine occur interstitially in a mosaic of alkali feldspar and foids ("tinguaitic texture"; cf. [17]. The associated phonolites are very fine grained, sometimes porphyritic, with the same mineralogical association of the coexisting tinguaites.

The granitic dyke of the Lugiin Gol complex is mainly course, but locally also very coarse, with large phenocrysts of microcline, oligoclase, biotite and quartz set in a groundmass made of the same phases. Accessory minerals are mainly amphibole, titanite, apatite, magnetite and ilmenite.

\subsection{Carbonatites}

According to Kynicky and Samec [11] and Kynicky et al. 
$[18,19]$, the carbonatites are mainly sővite and alvikite, consisting essentially of calcite, minor to accessory apatite and fluorite, fluorcarbonates, strontianite, barite, celestine and quartz. The textures of examined carbonatites usually show a recrystallization of magmatic calcite, alteration of apatite, and crystallization of minerals controlled by the intensity of hydrothermal-metasomatic alteration [14,20,21]. It is suggested that there are two types of alteration in the carbonatites: 1) high temperature (above $250^{\circ} \mathrm{C}, \max 400^{\circ} \mathrm{C}$ ) fluoritization with crystallization of fluorocarbonates (e.g. bastnaesite-(Ce), synchysite-(Ce), Ce- and Nd-parisite); 2) low temperature (bellow $150^{\circ} \mathrm{C}$ ) with crystallization of barite, celestine and quartz (up to the stage IV of [22]).

Notably, carbonatites usually form veins within magmatic rocks, or they are mainly located in brecciated rocks and eruptive breccias. There are rare crater facies at the contact of syenite plutons [3]. On the whole the carbonatitic rocks from the three complexes are similar, but Mushgai Khudag complex shows relatively high concentrations of apatite, and barite-celestine as well fluorocarbonates may be important in the veins from Bayan Khoshuu complex.

\section{Petrochemistry}

\subsection{Classification and Nomenclature}

The classification and nomenclature is after the TAS
$[17,23,24]$ cf. Figure 5(a)), and on the basis of QAPF diagram [16]. The silicate rocks of the analyzed complexes are rich in alkalis, with total alkali content $\left(\mathrm{Na}_{2} \mathrm{O}\right.$ $+\mathrm{K}_{2} \mathrm{O}$ ) ranging from 10.1 to $16.7 \mathrm{wt} \%$ (cf. Tables 1 and 2): on the basis of the $\mathrm{Na}_{2} \mathrm{O} / \mathrm{K}_{2} \mathrm{O}$ ratio they are "potassic"; only one phonolitic (tinguaitic) dyke from Lugiin Gol complex plots inside the "highly potassic" field (Figure 5(b)). Agpaitic index ranges from 0.76 to 1.18 pointing to a tendency towards peralkaline rock-types. Silica and $\mathrm{MgO}$ contents range from 52.0 to 58.7 and from 3.48 to $0.11 \mathrm{wt} \%$, respectively, indicating that the rocks are evolved (from intermediate to acid, following) [23]. Analogously to similar occurrences, the rocks may derive, via fractional crystallization, by original basanitic magmas $[22,25,26]$.

The analyzed samples (Tables 1 and 2), plotted in the TAS (Figure 5(a)), are: 9 foid syenites, 5 foid bearing monzonites, 1 monzonites, 2 phonolites, 6 phonolites with tinguaitic texture, 7 monzonites and 2 syenites, other than the alkali granite dyke (4 samples) of the Lugiin Gol complex.

Following the Q-A-P-F classification, where the distribution of the $\mathrm{Ab}$ molecule between alkali feldspar and plagioclase was obtained according to Le Maitre (1976) on the CIPW norms (Figure 5(c)), the samples are foidsyenites/phonolites and foid bearing syenites/trachytes (Lugiin Gol) and syenites/trachytes (Mushgai Khudag and Bayan Khoshuu).
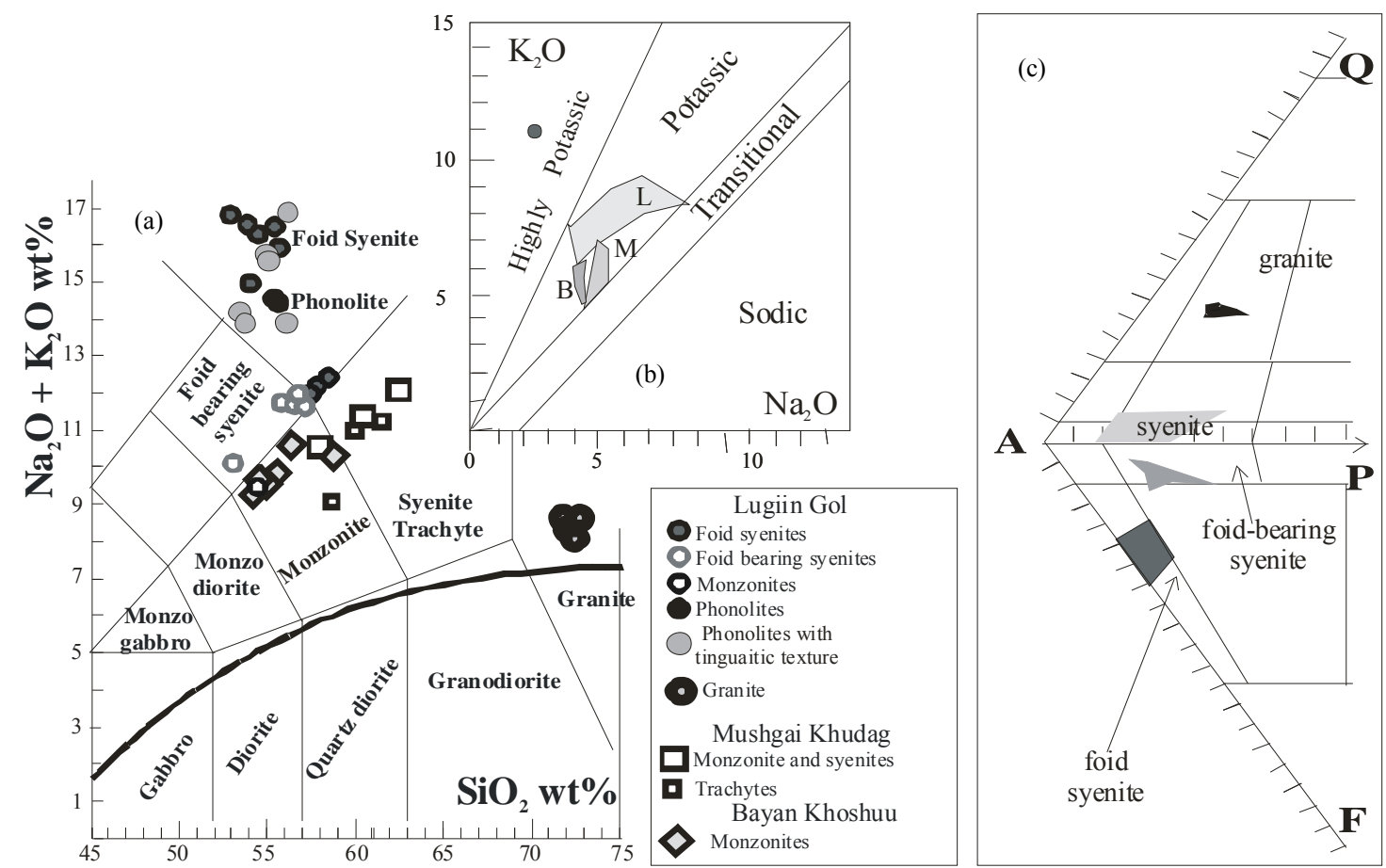

Figure 5. (a) Total alkali-silica diagram, TAS, modified after Middlemost, 1994. Heavy line separates alkaline and subalkaline fields [27]; (b) $\mathrm{Na}_{2} \mathrm{O}$ vs $\mathrm{K}_{2} \mathrm{O}$ diagram; L, Lugiin Gol, M, Mushgai Khudag, B, Bayan Khoshuu; (c) In the Q-A-P-F diagram [16] the normative values were plotted after the sharing out Ab between alkali feldspar and plagioclase [28]. 
Table 1. Major element concentrations (wt \%) for the Lugiin Gol selected samples and relative CIPW norms. APF calculated following [28]. Major elements were analyzed by XRF fluorescence techniques at the Shimane University, Japan (Department of Geosciences, Lagoon Research Center); FeO contents were determined by the $\mathrm{KMnO}_{4}$ solution titration method. Nomenclature according to QAPF of [16,29]. A.I.: agpaitic index, molecular ratio of $\left(\mathrm{Na}_{2} \mathrm{O}+\mathrm{K}_{2} \mathrm{O}\right) / \mathrm{Al}_{2} \mathrm{O}_{3}$.

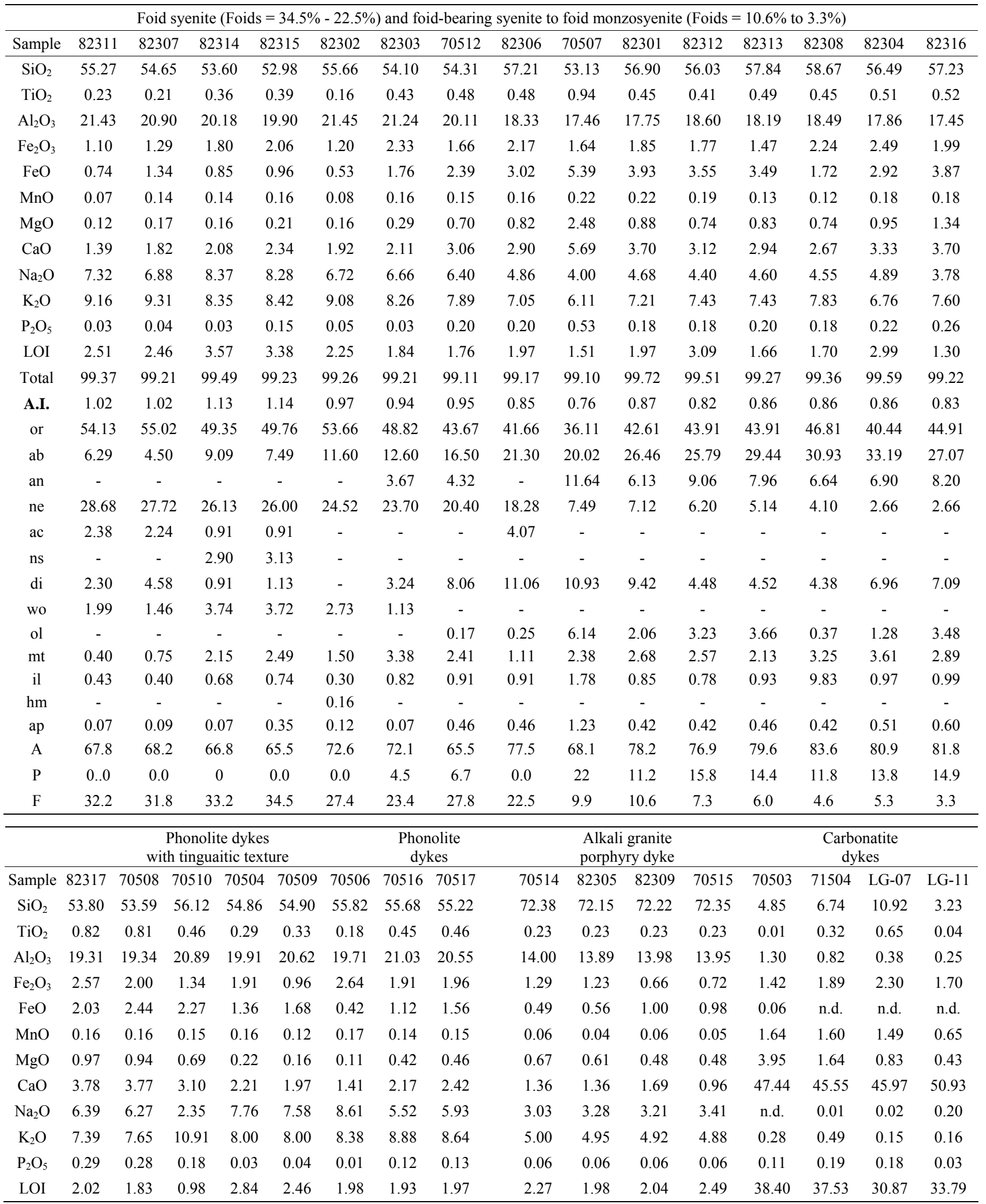




\begin{tabular}{|c|c|c|c|c|c|c|c|c|c|c|c|c|c|c|c|c|c|}
\hline Total & 99.53 & 99.08 & 99.45 & 99.55 & 98.82 & 99.44 & 99.37 & 99.45 & & 100.84 & 100.34 & 100.55 & 100.56 & 99.46 & 96.78 & 93.8 & 91.4 \\
\hline A.I. & 0.96 & 0.96 & 0.75 & 1.08 & 1.03 & 1.18 & 0.89 & 0.93 & & 0.74 & 0.77 & 0.76 & 0.78 & & & & \\
\hline Q & - & - & - & - & - & - & - & - & & 31.79 & 30.42 & 29.92 & 30.65 & & & & \\
\hline $\mathrm{C}$ & - & - & - & - & - & - & - & - & & 1.20 & 0.77 & 0.30 & 1.31 & & & & \\
\hline or & 43.67 & 45.21 & 64.48 & 47.28 & 47.28 & 49.52 & 52.48 & 51,17 & & 29.55 & 29.25 & 29.08 & 28.84 & & & & \\
\hline$a b$ & 15.97 & 14.19 & 5.60 & 8.83 & 11.86 & 9.00 & 14.90 & 13.94 & & 25.64 & 27.76 & 27.16 & 28.86 & & & & \\
\hline an & 2.18 & 2.03 & 14.21 & - & - & - & 6.38 & 3.94 & & 6.55 & 6.47 & 8.39 & 4.76 & & & & \\
\hline ne & 6.24 & 21.06 & 7.74 & 27.39 & 26.91 & 24.77 & 17.23 & 19.63 & & - & - & - & - & & & & \\
\hline $\mathrm{ac}$ & - & - & - & 5.53 & 2.31 & 7.64 & - & - & & - & - & - & - & & & & \\
\hline $\mathrm{ns}$ & - & - & - & - & - & 2.20 & - & - & & - & - & - & - & & & & \\
\hline $\mathrm{di}$ & 6.24 & 6.39 & - & 5.48 & 5.80 & 2.08 & 2.26 & 3.91 & & - & - & - & - & & & & \\
\hline wo & 2.85 & 3.24 & - & 1.82 & 1.31 & 1.88 & 0.29 & 1.01 & & & - & - & - & & & & \\
\hline hy & - & - & - & - & - & - & - & - & & 1.93 & 1.52 & 2.22 & 2.11 & & & & \\
\hline ol & - & - & 3.20 & - & - & - & - & - & & - & - & - & - & & & & \\
\hline $\mathrm{mt}$ & 3.73 & 2.90 & 1.94 & - & 0.24 & - & 2.76 & 2.84 & & 1.11 & 1.29 & 0.96 & 1.04 & & & & \\
\hline il & 1.56 & 1.54 & 0.87 & 0.55 & 0.63 & 0.34 & 0.85 & 1.15 & & 0.43 & 0.43 & 0.43 & 0.43 & & & & \\
\hline $\mathrm{hm}$ & - & - & - & - & - & - & 0.03 & - & & 0.53 & 0.35 & - & - & & & & \\
\hline ap & 0.67 & 0.65 & 0.42 & 0.07 & 0.09 & 0.02 & 0.28 & 0.30 & & 0.10 & 0.10 & 0.10 & 0.10 & & & & \\
\hline A & 71.4 & 71.3 & 75.1 & 67.2 & 68.7 & 68.5 & 72.3 & 72.3 & $\mathrm{Q}$ & 34.0 & 32.4 & 31.6 & 32.9 & & & & \\
\hline $\mathrm{P}$ & 3.6 & 3.2 & 16.5 & 0.0 & 0.0 & 0.0 & 8.8 & 5.6 & A & 54.0 & 55.4 & 51.31 & 57.6 & & & & \\
\hline F & 25.0 & 25.5 & 8.4 & 32.8 & 31.3 & 31.5 & 18.9 & 22.1 & $\mathrm{P}$ & 12.0 & 12.2 & 15.3 & 9.5 & & & & \\
\hline
\end{tabular}

Representative analyses of Ca-carbonatites are reported in the Tables $\mathbf{1}$ and 2, along the analyses of FREE rich variants from the Bayan Khoshuu complex.

\subsection{Geochemistry}

Notably, all the Lugiin Gol samples, granitic dyke excepted, are Ne normative (Ne 2.66 to 28.68 wt\%; cf. Table 1), whereas the alkaline rocks from the Mushgai Khudag and Bayan Khoshuu are oversaturated or saturated in silica $(\mathrm{Q}=0.0$ to $7.6 \mathrm{wt} \%$; $\mathrm{cf}$. Table 2). All the samples display a variable $\mathrm{Al}_{2} \mathrm{O}_{3}$ content (14.74 - 17.96 $w t \%)$. On the whole, the rocks appear enriched in LILE and depleted in HFS elements such as $\mathrm{Nb}$, Ta, $\mathrm{P}$ and $\mathrm{Ti}$. They show a strongly enriched pattern in $\mathrm{Pb}$ (Tables 3, 4 and Figure 6). On the other hand, the rocks are enriched in LREE and depleted in HREE (showing flat patterns), with a weak negative Eu anomaly (Tables 3, 4 and Figure 7).

In particular, the carbonatite dykes and veins from the complexes (Figure 7 and Tables 3, 4) show a very high concentration of $\mathrm{U}$, Th, (up to 3843 and 114, ppm, respectively) and REE (REE $=0.6$ - 3.3, up to $23.5 \mathrm{wt} \%$; $\mathrm{LREE}=6928$ up to $224,291 \mathrm{ppm})$ and a very strong fractionation LREE/HREE $(\mathrm{Nd} / \mathrm{Lu}=854-24,100)$. It can be stressed that the highest values are typical of the later veins from Bayan Khoshuu complex and "high grade" carbonatites from Lugiin Gol complex, linked to the presence of fluorocarbonate minerals as bastnaesite, synchysite and parisite: this suggests an economic importance for these occurrences, almost for LREE (cf. also [30] and therein references). As matter of fact, from mass balance (Tables 2 and 4) the MK vein contains approximately barite $13 \mathrm{wt} \%$, celestine + strontianite $17 \mathrm{wt} \%$ and bastnaesite + synchysite + parisite (up to $28 \mathrm{wt} \%$ ). Moreover, an exceptional content of apatite is present in the MK-01 carbonatite (about 13.5 wt\%). Considering major and trace elements, REE contents of intrusive rocks from the Mushgai Khudag and Bayan Khoshuu complexes (shown in Tables 2 and 4), it is apparent that these rocks are strongly enriched in $\mathrm{Sr}, \mathrm{Pb}$ and LILE and depleted in HFSE ( $\mathrm{Ta}, \mathrm{Nb}, \mathrm{Hf}, \mathrm{Ti}$, and $\mathrm{Y}$ ) (Figure 6). They show enriched LREE pattern (Figure 7). Geochemically these rocks are characterized by relatively low HFSE with enrichment in LILE and LREE, depletion in $\mathrm{Ta}, \mathrm{Nb}$, Ti and $\mathrm{Zr}$ with HFSE troughs on the primordial mantle normalized spiderdiagrams [31], which are commonly observed in island arc basalts and in the Paraná volcanic, the latter linked to extensional (rifting) processes [32]. It suggests that the original (basanitic?) magmas were derived from continental lithospheric, mantle, metasomatized by fluids, variably enriched in $\mathrm{CO}_{2}$ and $\mathrm{H}_{2} \mathrm{O}$ (and F, LILE and so on: cf. veined mantle of $[33,34]$. On the whole, all the data, suggest that the Mongolian alkaline complexes from southern Mongolia are related to the lithospheric mantle, where the contribution of asthenospheric components are not appreciable in terms of geochemical signatures (cf. [32], and therein 
Table 2. Major element compositions (wt\%) for selected intrusive samples from Mushgai Khudag and Bayan Khoshuu complexes. Effusive selected samples are from [5]; $\mathrm{Fe}_{2} \mathrm{O}_{3}-\mathrm{FeO}$ partitioning determined by $\mathrm{Ox}$ of [28]. Carbonatite dyke and $\mathrm{F}$ carbonate veins are from[19] ( unpublished data).

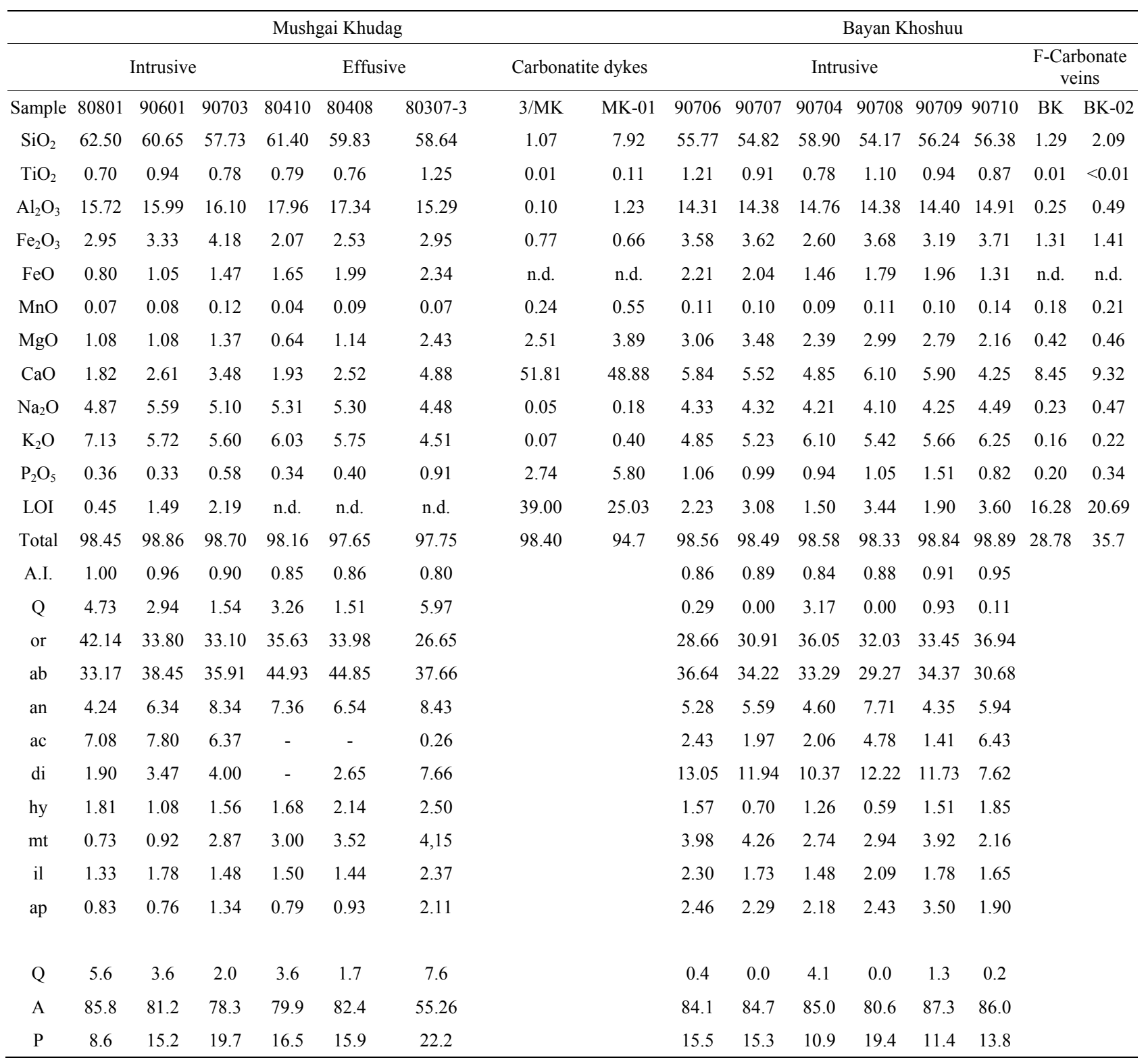
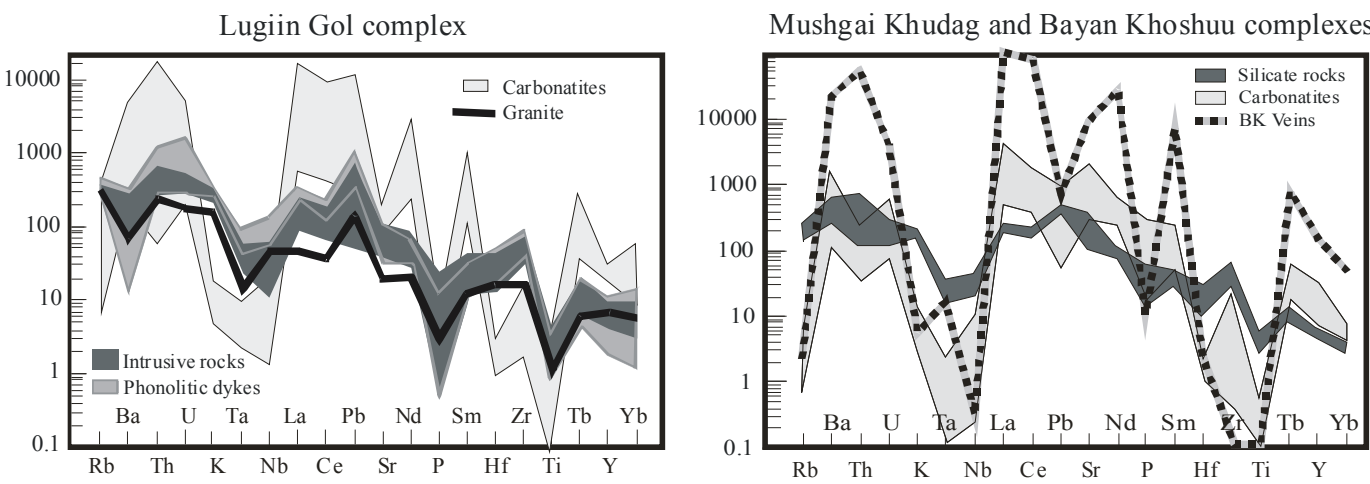

Figure 6. Primitive mantle normalized [31] spidergram for the Lugiin Gol, Mushgai Khudag and Bayan Khoshuu complexes. 
Table 3. Trace element concentrations (ppm) for the Lugiin Gol selected samples; trace elements were determined by ICP-Mass Spectrometer (Shimane University) by alkali fusion and acid digestion methods; n.d., not determined. Nomenclature according to the TAS.

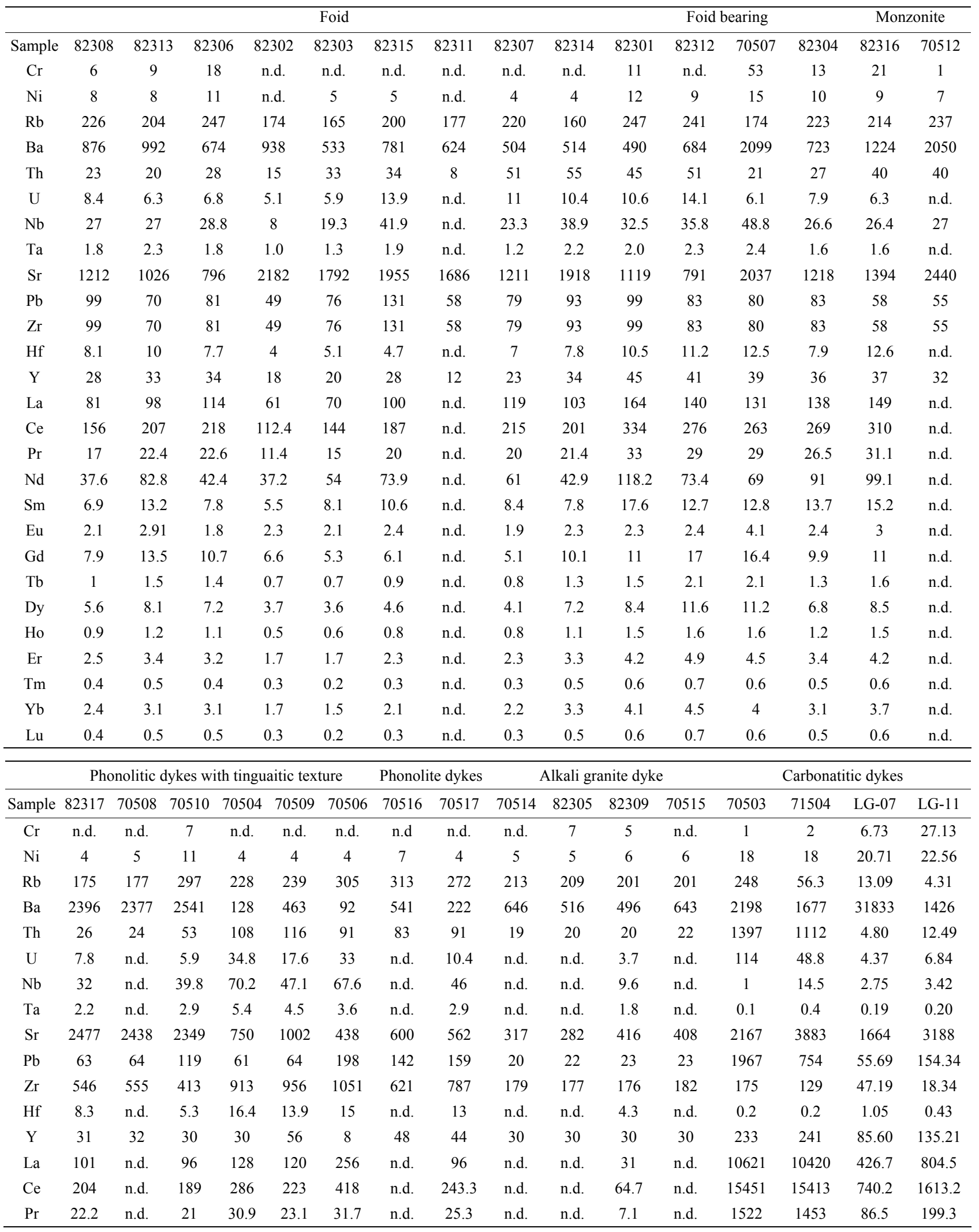


Continued

\begin{tabular}{ccccccccccccccccc}
\hline $\mathrm{Nd}$ & 77.1 & n.d. & 39.9 & 99.8 & 54.7 & 72.2 & n.d. & 87.2 & n.d. & n.d. & 28.1 & n.d. & 3500 & 3871 & 329.2 & 756.8 \\
$\mathrm{Sm}$ & 12.2 & n.d. & 7.7 & 11.7 & 9.5 & 4.4 & n.d. & 15 & n.d. & n.d. & 5.5 & n.d. & 458.6 & 406.0 & 49.9 & 101.5 \\
$\mathrm{Eu}$ & 3.4 & n.d. & 2.7 & 2.7 & 2.5 & 0.8 & n.d. & 3.3 & n.d. & n.d. & 0.6 & n.d. & 92.4 & 83.0 & 18.1 & 31.5 \\
$\mathrm{Gd}$ & 8.4 & n.d. & 9.9 & 14.8 & 13.4 & 12.6 & n.d. & 16.2 & n.d. & n.d. & 4.8 & n.d. & 677 & 518 & 42.9 & 72.2 \\
$\mathrm{~Tb}$ & 1.2 & n.d. & 1.2 & 1.6 & 1.9 & 0.5 & n.d. & 2 & n.d. & n.d. & 0.7 & n.d. & 32 & 26.0 & 4.31 & 7.36 \\
$\mathrm{Dy}$ & 6.4 & n.d. & 6.6 & 8.4 & 10.8 & 2.6 & n.d. & 10.2 & n.d. & n.d. & 4.7 & n.d. & 180 & 182 & 17.89 & 26.03 \\
$\mathrm{Ho}$ & 1.2 & n.d. & 1 & 1.2 & 1.9 & 0.2 & n.d. & 1.5 & n.d. & n.d. & 0.9 & n.d. & 10.8 & 11.0 & 3.23 & 4.47 \\
$\mathrm{Er}$ & 3.2 & n.d. & 2.8 & 3.8 & 6.1 & 0.9 & n.d. & 4.5 & n.d. & n.d. & 2.9 & n.d. & 46.6 & 41.2 & 8.58 & 12.56 \\
$\mathrm{Tm}$ & 0.5 & n.d. & 0.4 & 0.6 & 1.1 & 0.1 & n.d. & 0.6 & n.d. & n.d. & 0.4 & n.d. & 4.3 & 4.6 & 0.82 & 1.25 \\
$\mathrm{Yb}$ & 3.1 & n.d. & 2.5 & 4.3 & 7.3 & 0.6 & n.d. & 4.3 & n.d. & n.d. & 2.8 & n.d. & 30 & 29.7 & 4.57 & 7.07 \\
$\mathrm{Lu}$ & 0.4 & n.d. & 0.4 & 0.7 & 1.1 & 0.1 & n.d. & 0.6 & n.d. & n.d. & 0.4 & n.d. & 4.1 & 4.0 & 0.61 & 0.94 \\
\hline
\end{tabular}

Table 4. Trace element concentrations (ppm) for selected intrusive samples from Mushgai Khudag and Bayan Khoshuu complexes.

\begin{tabular}{|c|c|c|c|c|c|c|c|c|c|c|c|c|c|c|c|c|}
\hline & & & & Mushg & ai Khu & dag & & & & & & Bayan I & Choshuu & & & \\
\hline & & Intrusiv & & & Effusi & & Carbon & itic dykes & & & Intr & sive & & & $\begin{array}{r}\text { F-Carb } \\
\text { vein }(4 / \\
\text { dyke ( } 8\end{array}$ & $\begin{array}{l}\text { bonatitic } \\
\text { /BK) and } \\
\text { 3/BK-02) }\end{array}$ \\
\hline Sample & 80801 & 190601 & 90703 & 80410 & 80408 & $80307-3$ & $3 / \mathrm{MK}$ & 8/MK-01 & 90706 & 90707 & 90704 & 90708 & 90709 & 90710 & 4/BK & 8/BK-02 \\
\hline $\mathrm{Cr}$ & n.d. & n.d. & 12 & n.d. & 5 & 25 & n.d. & 8.13 & 71 & 62 & 31 & 42 & 27 & 16 & n.d. & 12.23 \\
\hline $\mathrm{Ni}$ & 15 & 4 & 6 & 12 & 11 & 32 & $<20$ & 12.62 & 62 & 56 & 38 & 46 & 40 & 27 & 26 & 5.15 \\
\hline $\mathrm{Rb}$ & 178 & 136 & 97 & 110 & 109 & 88 & 3.9 & 0.41 & 87 & 89 & 108 & 94 & 96 & 110 & 1.5 & 2.57 \\
\hline $\mathrm{Ba}$ & 2409 & 1934 & 3024 & 1994 & 2260 & 2462 & 750 & 5027 & 3892 & 3992 & 3757 & 4094 & 4778 & 4060 & 115540 & 9580 \\
\hline $\mathrm{Th}$ & 67 & 27 & 14 & n.d. & n.d. & n.d. & 17.1 & 2.59 & 13 & 16 & 11 & 15 & 13 & 25 & 3843 & 11.02 \\
\hline $\mathrm{U}$ & n.d. & 6 & 2.8 & n.d. & n.d. & n.d. & 11.5 & 8.89 & 5.5 & 3.4 & n.d. & 3.81 & n.d. & 6.8 & 68 & 5.57 \\
\hline $\mathrm{Nb}$ & n.d. & 26.8 & 14.8 & 24 & 17 & 11 & 6.0 & 0.16 & 16.1 & 13.4 & n.d. & 18.27 & n.d. & 22.3 & $<0.5$ & 0.40 \\
\hline $\mathrm{Ta}$ & n.d. & 1.4 & 0.67 & n.d. & n.d. & n.d. & $<0.1$ & 0.01 & 0.9 & 0.9 & n.d. & 1.04 & n.d. & 1.2 & 0.6 & 0.08 \\
\hline $\mathrm{Sr}$ & 2465 & 2222 & 3508 & 3057 & 3733 & 2588 & 5680 & 26628 & 9006 & 5429 & 4542 & 5375 & 5771 & 4824 & 147272 & 39500 \\
\hline $\mathrm{Pb}$ & 84 & 104 & 76 & n.d. & n.d. & n.d. & 8.0 & 149.87 & 73 & 70 & 65 & 69 & 68 & 80 & 107 & 52.85 \\
\hline $\mathrm{Zr}$ & 703 & 709 & 331 & 233 & 127 & 169 & 244 & 10.91 & 368 & 406 & 461 & 434 & 362 & 574 & 0.7 & 4.86 \\
\hline $\mathrm{Hf}$ & n.d. & 8.7 & 3.4 & n.d. & n.d. & n.d. & $<0.5$ & 0.23 & 3 & 4 & n.d. & 3.92 & n.d. & 6.2 & $<0.5$ & 0.53 \\
\hline $\mathrm{Y}$ & 23 & 23 & 26 & 36 & 34 & 18 & 131 & 31.40 & 23 & 21 & 23 & 24 & 29 & 31 & 592 & 103.17 \\
\hline $\mathrm{La}$ & n.d. & 150.4 & 152.3 & n.d. & n.d. & n.d. & 2517 & 1826.0 & 178.2 & 154 & n.d. & 183.87 & n.d. & 200 & 59830 & 309.9 \\
\hline $\mathrm{Ce}$ & n.d. & 295 & 312 & n.d. & n.d. & n.d. & 2636 & 1620.0 & 350.2 & 287.8 & n.d. & 347.62 & n.d. & 458.34 & 120066 & 610.4 \\
\hline $\operatorname{Pr}$ & n.d. & 29.8 & 35.2 & n.d. & n.d. & n.d. & 844 & 110.8 & 37.7 & 31.4 & n.d. & 37.84 & n.d. & 48.6 & 10818 & 76.3 \\
\hline $\mathrm{Nd}$ & n.d. & 107 & 128.5 & 177 & 165 & n.d. & 773 & 288.4 & 143.7 & 76.3 & n.d. & 144.3 & n.d. & 175.4 & 39765 & 299.9 \\
\hline $\mathrm{Sm}$ & n.d. & 14.9 & 18.9 & 28.1 & 34.6 . & n.d. & 91.4 & 22.0 & 20.7 & 13 & n.d. & 20.6 & n.d. & 24.5 & 2555 & 46.8 \\
\hline $\mathrm{Eu}$ & n.d. & 3.4 & 5.0 & n.d. & n.d. & n.d. & 32.4 & 8.8 & 5.2 & 4.9 & n.d. & 5.26 & n.d. & 6.3 & 512 & 13.9 \\
\hline Gd & n.d. & 8.2 & 11.2 & n.d. & n.d. & n.d. & 31.8 & 34.0 & 15.0 & 17.4 & n.d. & 14.16 & n.d. & 16.1 & 745 & 34.5 \\
\hline $\mathrm{Tb}$ & n.d. & 1.0 & 1.3 & n.d. & n.d. & n.d. & 5.8 & 1.84 & 1.4 & 1.7 & n.d. & 1.27 & n.d. & 1.6 & 73 & 3.67 \\
\hline Dy & n.d. & 4.7 & 6.1 & n.d. & n.d. & n.d. & 16.2 & 5.63 & 6.0 & 8.4 & n.d. & 5.68 & n.d. & 7.2 & 200 & 14.89 \\
\hline Ho & n.d. & 0.8 & 1.0 & n.d. & n.d. & n.d. & 6.5 & 1.05 & 0.9 & 0.9 & n.d. & 0.9 & n.d. & 1.2 & 28 & 2.53 \\
\hline $\mathrm{Er}$ & n.d. & 2.1 & 2.5 & n.d. & n.d. & n.d. & 4.8 & 3.23 & 2.5 & 2.7 & n.d. & 2.24 & n.d. & 3.0 & 46.6 & 6.25 \\
\hline $\mathrm{Tm}$ & n.d. & 0.3 & 0.3 & n.d. & n.d. & n.d. & 0.5 & 0.32 & 0.3 & 0.3 & n.d. & 0.26 & n.d. & 0.4 & 3.3 & 0.62 \\
\hline $\mathrm{Yb}$ & n.d. & 1.7 & 1.9 & n.d. & n.d. & n.d. & 1.9 & 2.07 & 1.7 & 1.9 & n.d. & 1.55 & n.d. & 2.4 & 19.8 & 3.18 \\
\hline $\mathrm{Lu}$ & n.d. & 0.3 & 0.3 & n.d. & n.d. & n.d. & 0.4 & 0.29 & 0.3 & 0.3 & n.d. & 0.24 & n.d. & 0.3 & 1.65 & 0.39 \\
\hline
\end{tabular}



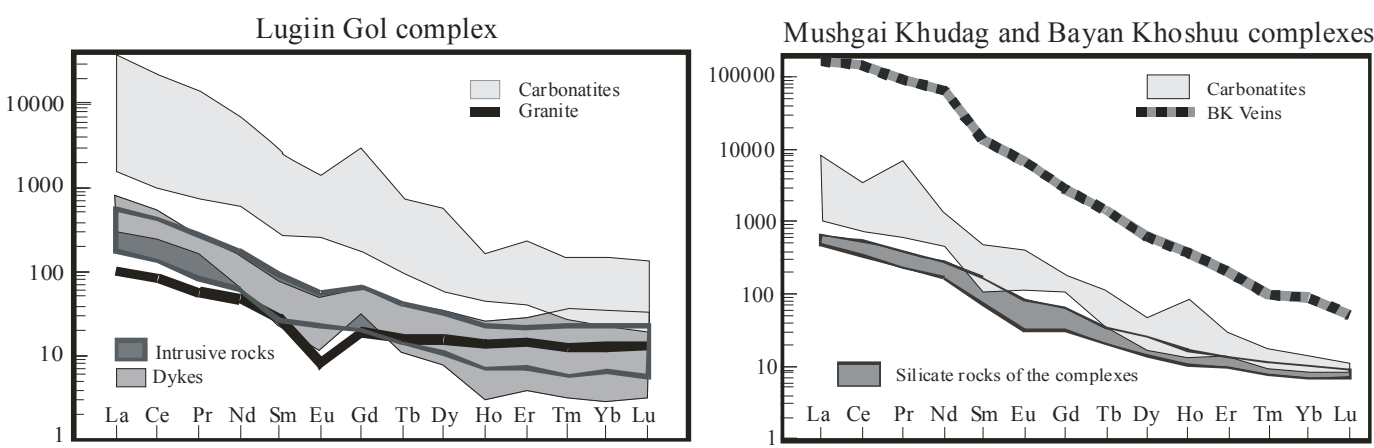

Figure 7. Chondrite normalized [35] REE pattern of the Lugiin Gol, Mushgai Khudag and Bayan Khoshuu complexes.

references).

\section{Age of the Complexes}

An errorchron calculated following the $\mathrm{Rb} / \mathrm{Sr}$ systematics on the syenitic rocks from Lugiin Gol complex gives an age of $244.9 \pm 22.4 \mathrm{Ma}$ (initial $\mathrm{Sr}$ isotope ratio, $\mathrm{Sr}_{\mathrm{i}}$, = 0.70800 ; Figure 8(a)), roughly corresponding to "Sensitive High Resolution Ion Microprobe" (SHRIMP) ages $(245-240 \mathrm{Ma})$ on the zircons from the same complex [19]. On the other hand, the whole rock-minerals isochron ages where determined for the three complexes by $\mathrm{Rb}-\mathrm{Sr}$ method: ${ }^{87} \mathrm{Rb} /{ }^{86} \mathrm{Sr}$ and ${ }^{87} \mathrm{Sr} /{ }^{86} \mathrm{Sr}$ data are reported in Table 5. A Lugiin Gol undersaturated syenite sample shows an age of $222.2 \pm 3.2(2 \sigma)$ Ma with $\mathrm{Sr}_{\mathrm{i}}=$ $0.70811 \pm 0.00009$ (foid syenite 82306 , Figure 8(b)); the Mushgai Khudag syenite (sample 90703) displays 139.9 $\pm 5.9 \mathrm{Ma}$ and $\mathrm{Sr}_{\mathrm{i}}=0.70605 \pm 0.00008$ (Figure 8(d)); Bayan Khoshuu syenite (sample 90710) has an age = $130.6 \pm 9.3 \mathrm{Ma}$ with $\mathrm{Sr}_{\mathrm{i}}=0.70594 \pm 0.00009$ (Figure 8(e)).

Notably the $\mathrm{Rb}-\mathrm{Sr}$ age from the isochron relative to the foid syenite from Lugiin Gol is too low (222 vs. $245 \mathrm{Ma}$ ) with respect to the whole complex: the younger age is probably due to the alteration processes that affected some host rocks after the intrusions of the dyke systems.

On the contrary, the Rb-Sr ages of the Mushgai Khudag and Bayan Khoshuu complexes are similar 1) to those reported by JICA [15] utilizing K-Ar systematic; and 2$)$ to the $\mathrm{Sm} / \mathrm{Nd}$ calculated ages $(138 \pm 3$ and $134 \pm 2$, Mushgai Khudag and Bayan Khoshuu, respectively) .

An errorchron for the granitic dyke intruding the Lugiin Gol complex (cf. Table 5) gives an age of 209.9 \pm $0.9 \mathrm{Ma}\left(\mathrm{Sr}_{\mathrm{i}}=0.70765\right.$; Figure 8(c)).

Moreover, an errorchron (not shown) relative to the whole rocks from Lugiin Gol foid syenites to foid-bearing syenites + associated phonolitic dykes and carbonatitic dyke, give the same age of the intrusive rocks, i.e. $244.9 \pm 22.4 \mathrm{Ma}$. However this age, in our opinion, cannot be accepted because: 1) it is unlikely that the intruding dykes have the same age of the complex; 2) the Sm-Nd systematic does not show any correlation. An age younger than $222 \mathrm{Ma}$ (probable age of hydrothermal alteration on the foid syenite 82306), or similar to that of the granitic dyke, i.e. $210 \mathrm{Ma}$, may be believed most probable also for phonolitic and carbonatitic dykes.

At any way, a Mesozoic age is confirmed, i.e. Triassic for Lugiin Gol complex, and Early Cretaceous for Mushgai Khudag and Bayan Khoshuu complexes.

\section{Sr-Nd Systematics}

All the available isotopic data, initial ${ }^{87} \mathrm{Sr} /{ }^{86} \mathrm{Sr}\left(\mathrm{Sr}_{\mathrm{i}}\right)-$ ${ }^{143} \mathrm{Nd} /{ }^{144} \mathrm{Nd}\left(\mathrm{Nd}_{\mathrm{i}}\right)$ and $\varepsilon \mathrm{Sr}-\varepsilon \mathrm{Nd}$ notation are reported in Table 6 along with the model age $\left(\mathrm{T}^{\mathrm{DM}}\right)$ relative to the depleted mantle [38]. Lugiin Gol complex (calculated using the previous age results; cf. Figure 8) are in the ranges $0.70772-0.70827,0.51216-0.51226$ and $49.81-$ $57.07,-4.24--1.25$, respectively (syenitic variants: age $245 \mathrm{Ma}$ ); the phonolitic dykes (222 Ma) have $\mathrm{Sr}_{\mathrm{i}} 0.70745$ - 0.70888 and $\mathrm{Nd}_{\mathrm{i}} 0.51220-0.51228$, with $\varepsilon \mathrm{Sr}$ and $\varepsilon \mathrm{Nd}$ varying between 45.54 and 66.36 , and between -3.02 and -1.73 , respectively. The latter are similar to the carbonatitic dyke $(\varepsilon \mathrm{Sr}=64.88$ and $\varepsilon \mathrm{Nd}=-1.53)$. Notably, all these samples plot in the IV quadrant in the $\mathrm{Sr}_{\mathrm{i}} \mathrm{vs} . \mathrm{Nd}_{\mathrm{i}}$ diagram (Figure 9): according to [39] and therein references) these volcanics were enriched in $\mathrm{Rb}\left(f_{\mathrm{Rb}}>0\right)$ and depleted in $\operatorname{Sm}\left(f_{\mathrm{Sm}}<0\right)$, indicating that a hypothetical basalt source or may has formed by contamination by igneous and metamorphic rocks of the continental crust or, more probably remained isolated for a sufficient time to acquire distinctive isotopic composition of $\mathrm{Sr}$ and $\mathrm{Nd}$.

The granitic dyke shows a slight enrichment in $\mathrm{Nd}$ $(\varepsilon \mathrm{Nd}+0.48$ to +1.27$)$, but with $\varepsilon \mathrm{Sr}(47.4-48.9)$ inside the same compositional variation of the phonolitic dykes, indicating a coupled enrichment in both $\mathrm{Rb}$ and $\mathrm{Sm}$.

The Mushgai Khudag syenites-trachytes have, as average, $\mathrm{Sr}_{\mathrm{i}}=0.70605 \pm 0.00001$ and $\mathrm{Nd}_{\mathrm{i}}=0.51244$, corresponding to $\varepsilon \mathrm{Sr}=24.3$ and $\varepsilon \mathrm{Nd}=-0.33$, respectively (cf. Table 6).

Bayan Khoshuu syenites-monzonites show $\mathrm{Sr}_{\mathrm{i}}=$ $0.70594(\varepsilon \mathrm{Sr}=22.6)$, similar to the Mushgai Khudag volcanic-plutonic complex, but the $\mathrm{Nd}_{\mathrm{i}}=0.51224(\varepsilon \mathrm{Nd}=-4.4)$ indicate a major depletion in Sm in the source (Figure 9). 

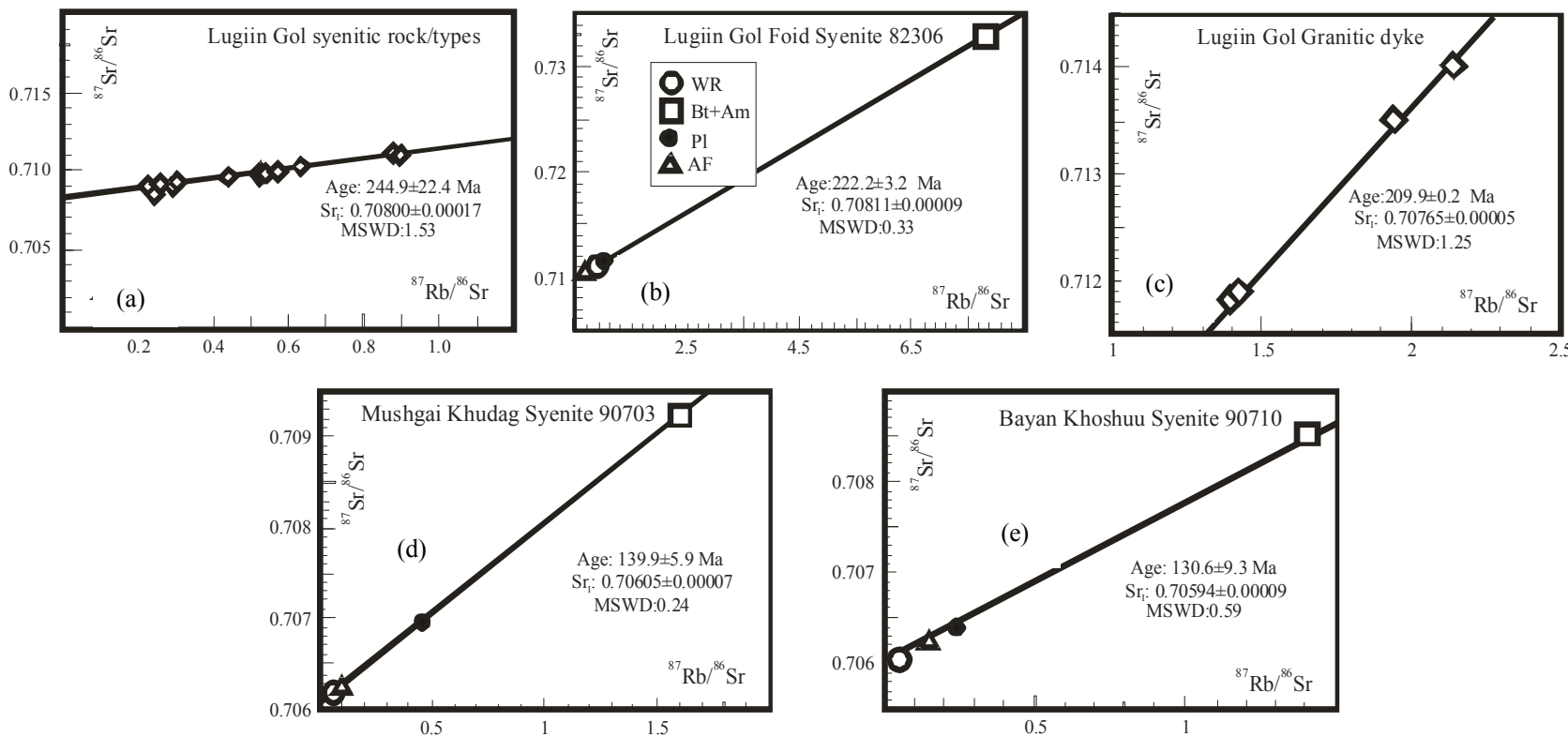

Figure 8. (a) Errorchron relative to the syenitic rocks (from foid syenites to foid bearing syenites) from Lugiin Gol complex; (b) Isochron for Lugiin Gol foid syenite 82306; (c) Errorchron for the samples from granitic dyke intruding the Lugiin Gol complex (cf. Tables 5 and 6); (d) Isochron for Mushgai Khudag syenite 90703; (e) Isochron for Bayan Khoshuu syenite 907010 ([36,37], unpublished data).

Table 5. ${ }^{87} \mathrm{Rb} /{ }^{86} \mathrm{Sr}$ and ${ }^{87} \mathrm{Sr} /{ }^{86} \mathrm{Sr}$ ratios for selected samples and minerals from Mongolian complexes (s. Table 6; cf. Figure 8).

\begin{tabular}{|c|c|c|c|c|c|c|c|}
\hline Sample no. & ${ }^{87} \mathrm{Rb} /{ }^{86} \mathrm{Sr}$ & ${ }^{87} \mathrm{Sr} /{ }^{86} \mathrm{Sr}(2 \sigma)$ & ${ }^{87} \mathrm{Sr} /{ }^{86} \mathrm{Sr}$ & Sample no. & ${ }^{87} \mathrm{Rb} /{ }^{86} \mathrm{Sr}$ & ${ }^{87} \mathrm{Sr} /{ }^{86} \mathrm{Sr}(2 \sigma)$ & ${ }^{87} \mathrm{Sr} /{ }^{86} \mathrm{~S}$ \\
\hline $\begin{array}{l}\text { Lugiin Gol } \\
\text { Foid Syenite }\end{array}$ & & measured & initial & Mushgai Khudag Syenite & & measured & initial \\
\hline $82306 \mathrm{WR}$ & 0.8981 & $0.711022(11)$ & 0.70816 & $90703 \mathrm{WR}$ & 0.080 & $0.706209(9)$ & 0.70605 \\
\hline $\mathrm{bt}+\mathrm{amph}$ & 7.8253 & $0.732846(9)$ & 0.70807 & $\mathrm{bt}+\mathrm{amph}$ & 1.611 & $0.709250(8)$ & 0.70605 \\
\hline plg & 0.6906 & $0.710325(14)$ & 0.70811 & plg & 0.461 & $0.706966(9)$ & 0.70605 \\
\hline $\mathrm{kfs}$ & 1.0815 & $0.711577(13)$ & 0.70814 & $\mathrm{kfs}$ & 0.104 & $0.706267(9)$ & 0.70606 \\
\hline Mean & & & 0.70811 & & & & 0.70605 \\
\hline Granitic dyke & & & & Bayan Khoshuu Syenite & & & \\
\hline $70514 \mathrm{WR}$ & 1.9452 & $0.713511(9)$ & 0.707702 & $90710 \mathrm{WR}$ & 0.066 & $0.706062(9)$ & 0.70594 \\
\hline $82305 \mathrm{WR}$ & 2.1456 & $0.714002(9)$ & 0.707594 & $\mathrm{bt}+\mathrm{amph}$ & 1.404 & $0.708544(7)$ & 0.70594 \\
\hline $82309 \mathrm{WR}$ & 1.3985 & $0.711814(9)$ & 0.707638 & plg & 0.244 & $0.706393(8)$ & 0.70595 \\
\hline $70515 \mathrm{WR}$ & 1.4259 & $0.711890(10)$ & 0.707632 & $\mathrm{kfs}$ & 0.141 & $0.706202(9)$ & 0.70594 \\
\hline Mean & & & 0.70764 & & & & 0.70594 \\
\hline
\end{tabular}

Although the rock-types of the examined complexes are strongly evolved, however the almost constant behaviour of the $\mathrm{Sm} / \mathrm{Nd}$ ratio in the analyzed samples $\left({ }^{147} \mathrm{Sm} /{ }^{144} \mathrm{Nd}=0.0100 \pm 0.017\right)$ allows to consider the $\mathrm{Nd}$ model ages as indicative of the main metasomatic events affecting the lithospheric sources beneath the Mongolian regions. The model ages, calculated in relation to the depleted mantle ( $\mathrm{T}^{\mathrm{DM}}$; cf. Table 6) for the whole population (33 samples) fit $992 \pm 119$ Ma, indicating a Neoproterozoic event ended with the Mushgai Khudag complex (797 $\pm 110 \mathrm{Ma}$ ), according to [41]. The latter dates are similar to the youngest Os model ages (1.1 and $0.7-0.5$ Ga); [42] and may support significant melt extraction from the subcontinental mantle and/or metasomatic events.

\section{Concluding Remarks}

Alkaline complexes from southern Mongolia are controlled by E-W lineament. Mushgai Khudag (MKC) and Bayan Khoshuu (BAK) complexes are along the Main Mongolian lineament and Early Cretaceous aged (139 and $120 \mathrm{Ma}$, respectively). Notably carbonatitic stock 
Table 6. Sr-Nd systematic relative to the examined complexes. Sr and Nd isotope ratios of whole rock samples and minerals and $\mathrm{Rb}, \mathrm{Sr}, \mathrm{Sm}$ and Nd contents of minerals were measured using a MAT 262 thermal ionization mass spectrometer equipped with five collectors. Initial ${ }^{87} \mathrm{Sr} /{ }^{86} \mathrm{Sr}$ and ${ }^{143} \mathrm{Nd} /{ }^{144} \mathrm{Nd}$ data were calculated as follows: Lugiin Gol, 245, 222, 210 Ma, syenitic facies, phonolitic-carbonatitic dykes, granitic dyke, respectively; Mushgai Khudag, 140 Ma; Bayan Khoshuu, 131 Ma. The values were determinated according to [40]. $\mathrm{T}^{\mathrm{DM}}$ values: calculation of $\mathrm{Nd}$ model dates relative to a depleted reservoir (i.e. ${ }^{143} \mathrm{Nd} /{ }^{144} \mathrm{Nd}=0.513114$ and ${ }^{147} \mathrm{Sm} /{ }^{144} \mathrm{Nd}=0.222$, after [39]).

Lugiin Gol

Foid syenites

\begin{tabular}{cccccccccccccc}
\hline Sample no. & $\mathrm{Rb}$ & $\mathrm{Sr}$ & ${ }^{87} \mathrm{Rb}{ }^{86} \mathrm{Sr}$ & ${ }^{87} \mathrm{Sr}{ }^{86} \mathrm{Sr}(2)$ & ${ }^{87} \mathrm{Sr} /{ }^{86} \mathrm{Sr}$ & & $\mathrm{Nd}$ & $\mathrm{Sm}$ & ${ }^{147} \mathrm{Sm} /{ }^{144} \mathrm{Nd}$ & ${ }^{143} \mathrm{Nd} /{ }^{144} \mathrm{Nd}(2)$ & ${ }^{143} \mathrm{Nd} /{ }^{144} \mathrm{Nd}$ \\
\hline LG- & ppm & ppm & & measured & initial & $\varepsilon \mathrm{Sr}$ & $\mathrm{ppm}$ & $\mathrm{ppm}$ & & measured & initial & $\varepsilon \mathrm{Nd}$ & $\mathrm{T}^{\mathrm{DM}}$ \\
\hline 82308 & 226 & 1212 & 0.5396 & $0.709859(9)$ & 0.70798 & 53.43 & 37.6 & 6.9 & 0.1109 & $0.512422(9)$ & 0.512224 & -1.53 & 1030 \\
82313 & 204 & 1026 & 0.5754 & $0.709941(10)$ & 0.70794 & 52.83 & 83.5 & 13.7 & 0.0992 & $0.512406(8)$ & 0.512247 & -1.48 & 948 \\
82306 & 247 & 796 & 0.8981 & $0.711022(11)$ & 0.70789 & 52.21 & 42.4 & 7.8 & 0.1107 & $0.512395(9)$ & 0.512217 & -2.07 & 1071 \\
82302 & 174 & 2182 & 0.2307 & $0.708994(15)$ & 0.70819 & 56.43 & 32.5 & 5.0 & 0.0924 & $0.512337(9)$ & 0.512188 & -2.63 & 986 \\
82303 & 165 & 1792 & 0.2664 & $0.709163(10)$ & 0.70823 & 57.07 & 54.0 & 8.1 & 0.0907 & $0.512385(9)$ & 0.512239 & -1.62 & 911 \\
82315 & 200 & 1955 & 0.2960 & $0.708955(11)$ & 0.70794 & 52.94 & 73.9 & 10.6 & 0.0867 & $0.512382(9)$ & 0.512242 & -1.55 & 888 \\
82311 & 177 & 1686 & 0.3038 & $0.709231(9)$ & 0.70827 & 56.19 & 35.1 & 5.6 & 0.0965 & $0.512260(9)$ & 0.512243 & -4.24 & 1109 \\
82307 & 220 & 1211 & 0.5257 & $0.709967(12)$ & 0.70813 & 55.65 & 61.0 & 8.4 & 0.0832 & $0.512362(9)$ & 0.512229 & -1.85 & 887 \\
82314 & 160 & 1918 & 0.2414 & $0.708759(9)$ & 0.70792 & 52.57 & 42.9 & 7.8 & 0.1104 & $0.512401(8)$ & 0.512225 & -1.91 & 1045 \\
82304 & 223 & 1218 & 0.5298 & $0.709673(10)$ & 0.70783 & 51.28 & 90.9 & 13.7 & 0.0911 & $0.512304(9)$ & 0.512158 & -3.21 & 968 \\
\hline
\end{tabular}

Foid-bearing syenites

\begin{tabular}{|c|c|c|c|c|c|c|c|c|c|c|c|c|c|}
\hline 82301 & 247 & 1119 & 0.6388 & $0.710269(9)$ & 0.70804 & 54.35 & 118.2 & 17.6 & 0.0900 & $0.512386(9)$ & 0.512242 & -1.58 & 906 \\
\hline 82312 & 241 & 791 & 0.8818 & $0.711082(15)$ & 0.70801 & 53.87 & 73.4 & 12.7 & 0.1049 & $0.512401(10)$ & 0.512233 & -1.74 & 1001 \\
\hline 70507 & 174 & 2037 & 0.2472 & $0.708585(9)$ & 0.70772 & 49.81 & 69.0 & 13.0 & 0.1118 & $0.512390(9)$ & 0.512207 & -2.25 & 1105 \\
\hline 82304 & 223 & 1218 & 0.5298 & $0.709673(10)$ & 0.70783 & 51.28 & 90.9 & 13.7 & 0.0911 & $0.512304(9)$ & 0.512158 & -3.21 & 968 \\
\hline \multicolumn{14}{|c|}{ Monzonite } \\
\hline 82316 & 214 & 1394 & 0.4442 & $0.709605(11)$ & 0.70806 & 54.55 & 99.1 & 15.2 & 0.0927 & $0.512407(9)$ & 0.512258 & -1.25 & 900 \\
\hline \multicolumn{14}{|c|}{ Phonolites } \\
\hline 82317 & 175 & 2477 & 0.2044 & $0.708095(9)$ & 0.70745 & 45.54 & 77.7 & 12.2 & 0.0957 & $0.512383(21)$ & 0.512245 & -2.09 & 945 \\
\hline 70508 & 177 & 2438 & 0.2101 & $0.708168(9)$ & 0.70751 & 46.33 & n.d. & n.d. & & & & & \\
\hline 70504 & 228 & 750 & 0.8798 & $0.711164(9)$ & 0.70839 & 58.84 & 99.8 & 11.7 & 0.0708 & $0.512342(9)$ & 0.512239 & -2.21 & 834 \\
\hline 70509 & 239 & 1002 & 0.6903 & $0.710612(9)$ & 0.70843 & 59.50 & 54.7 & 9.5 & 0.1050 & $0.512416(9)$ & 0.512263 & -1.73 & 984 \\
\hline 70506 & 305 & 438 & 2.0162 & $0.715246(9)$ & 0.70888 & 65.85 & 58.2 & 3.9 & 0.0405 & $0.512320(9)$ & 0.512261 & -1.78 & 711 \\
\hline 70510 & 297 & 2349 & 0.3659 & $0.709723(9)$ & 0.70857 & 61.42 & 39.9 & 7.7 & 0.1161 & $0.512367(9)$ & 0.512198 & -3.02 & 1187 \\
\hline 70516 & 313 & 600 & 1.5102 & $0.713684(9)$ & 0.70892 & 66.36 & 66.5 & 13.0 & 0.1182 & $0.512395(21)$ & 0.512223 & -2.52 & 1144 \\
\hline 70517 & 272 & 562 & 1.4010 & $0.713062(11)$ & 0.70864 & 62.42 & 57.8 & 11.3 & 0.1182 & $0.512406(9)$ & 0.512234 & -2.30 & 1128 \\
\hline \multicolumn{14}{|c|}{ Carbonatite dyke } \\
\hline 70503 & 248 & 2167 & 0.3312 & $0.709857(8)$ & 0.70881 & 64.88 & 3500 & 458.6 & 0.0792 & $0.512389(12)$ & 0.512274 & -1.53 & 1154 \\
\hline \multicolumn{14}{|c|}{ Alkali granite porphyry dike } \\
\hline 70514 & 213 & 317 & 1.9452 & $0.713511(9)$ & 0.70770 & 48.93 & & & 0.1183 & $0.512564(17)$ & 0.512401 & 0.66 & 891 \\
\hline 82305 & 209 & 282 & 2.1456 & $0.714002(9)$ & 0.70759 & 47.40 & & & 0.1183 & $0.512555(13)$ & 0.512392 & 0.48 & 804 \\
\hline 82309 & 201 & 416 & 1.3985 & $0.711814(9)$ & 0.70764 & 48.01 & 28.1 & 5.5 & 0.1183 & $0.512593(9)$ & 0.512430 & 1.22 & 847 \\
\hline 70515 & 201 & 408 & 1.4259 & $0.711890(10)$ & 0.70763 & 47.93 & & & & & & & \\
\hline
\end{tabular}

\section{Mushgai Khudag}

Syenites-Trachytes

\begin{tabular}{cccccccccccccc}
\hline 80801 & 178 & 2465 & 0.209 & $0.706465(7)$ & 0.70605 & 24.33 & & & & & & & \\
90601 & 136 & 2222 & 0.177 & $0.706407(8)$ & 0.70606 & 24.34 & 107.0 & 14.9 & 0.084 & $0.512517(10)$ & 0.512440 & -0.35 & 718 \\
90703 & 97 & 3508 & 0.080 & $0.706209(9)$ & 0.70605 & 24.31 & 128.5 & 18.9 & 0.089 & $0.512522(11)$ & 0.512440 & -0.34 & 739 \\
80410 & 110 & 3057 & 0.104 & $0.706257(7)$ & 0.70605 & 24.31 & 177 & 28.1 & 0.096 & $0.512528(10)$ & 0.512440 & -0.35 & 774 \\
80408 & 109 & 3733 & 0.084 & $0.706217(8)$ & 0.70604 & 24.30 & 165 & 34.6 & 0.127 & $0.512556(12)$ & 0.512440 & -0.35 & 985 \\
\hline
\end{tabular}


Bayan Khoshuu

\begin{tabular}{ccccccccccccccc}
\multicolumn{10}{c}{ Syenites-Monzonites } \\
\hline 90706 & 87 & 9006 & 0.028 & $0.705992(7)$ & 0.70594 & 22.60 & 143.7 & 20.7 & 0.087 & $0.512324(9)$ & 0.512249 & -4.29 & 957 \\
90707 & 89 & 5429 & 0.047 & $0.706027(7)$ & 0.70594 & 22.58 & 76.3 & 13.0 & 0.103 & $0.512338(9)$ & 0.512250 & -4.29 & 1069 \\
90708 & 94 & 5375 & 0.051 & $0.706037(6)$ & 0.70594 & 22.64 & 144.3 & 20.6 & 0.109 & $0.512343(9)$ & 0.512269 & -3.91 & 929 \\
90710 & 110 & 4824 & 0.066 & $0.706061(9)$ & 0.70594 & 22.57 & 175.4 & 24.5 & 0.085 & $0.512322(7)$ & 0.512250 & -4.29 & 940 \\
\hline
\end{tabular}

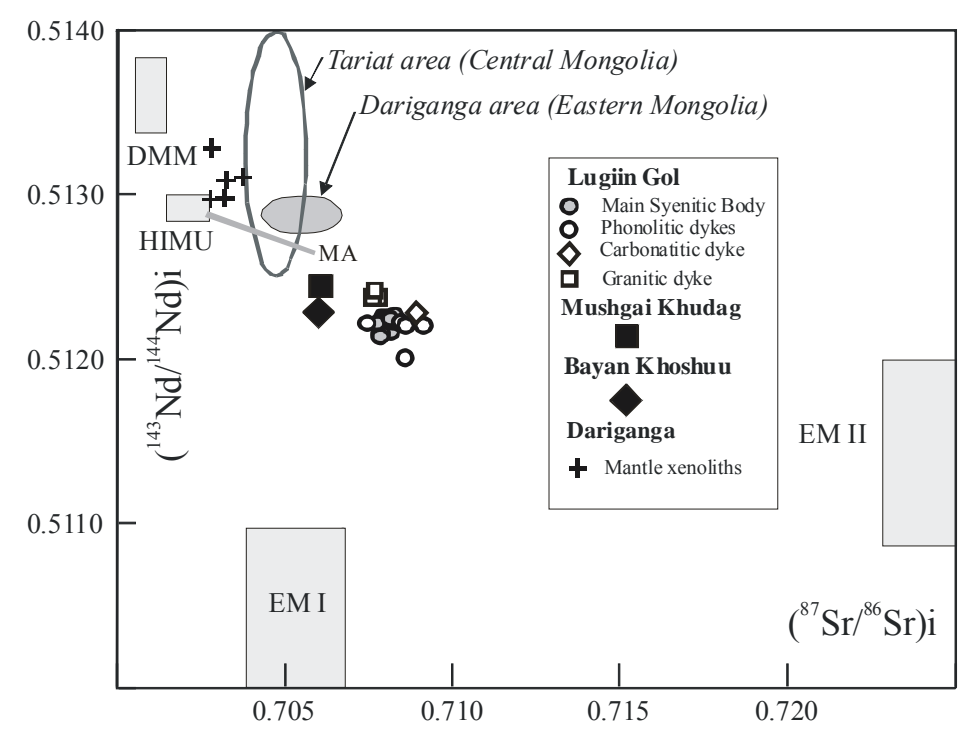

Figure 9. Time integrated $\left({ }^{87} \mathrm{Sr} /{ }^{86} \mathrm{Sr}\right) \mathrm{i}$ vs $(143 \mathrm{Nd} / 144 \mathrm{Nd}) \mathrm{f}$ for the Lugiin Gol, Mushgai Khudag and Bayan Khoshuu complexes. For the mantle components (DMM, HIMU, EMI and EMII) and Mantle Array (MA), s. [38,43-46]. Data sources for mantle xenoliths, Tariat and Dariganga areas: [42,47-49].

works are present in the two complexes. On the other hand, the Lugiin Gol (LGC) complex outcrops at the central-eastern Gobi-Tien Shan fold belt and it is Triassic in age (244 - $210 \mathrm{Ma})$. MKC and BAK consist mainly of slightly oversaturated syenites (monzonites) and trachytes, while in the LGC the rock-types are mainly foid-syenites and foid-bearing syenites and the complex is cut by a stockwork made of phonolitic and carbonatitic veins and dykes.

All the alkaline rocks are potassic, rarely highly potassic, and mainly intermediate silica-types, alkali granitic dyke excepted, and then they are believed derivative from a basic magma, probably a basanitic liquid, analogously to other world-wide occurrences and on the basis also of the trace element behavior ([50] and therein references); [32-34]; clinopyroxene and calcic plagioclase are evolving by fractional crystallization of olivine during ascent to the present position.

Stockworks of LREE rich carbonatites, carbonatefluorite, fluorite, and carbonate-fluorite-celestine-barite REE ore bearing rocks are associated with the complexes and point to an economic interest of the region.

On the whole, geochemical characteristics of alkaline complexes in South Mongolia were interpreted as formed within-plate tectonic environment and associated with extensional rift tectonics [3].
All the samples plot in the IV quadrant in the Sri vs. Ndi diagram showed enrichment in $\mathrm{Rb}\left(f_{\mathrm{Rb}}>0\right)$ and depletion in $\mathrm{Sm}\left(f_{\mathrm{Sm}}<0\right)$, indicating that a hypothetical basalt probably remained isolated for a sufficient time to gain distinctive isotopic composition of $\mathrm{Sr}$ and $\mathrm{Nd}$.

Finally, on the basis of almost constant behaviour of the $\mathrm{Sm} / \mathrm{Nd}$ ratio in the analyzed samples $\left({ }^{147} \mathrm{Sm} /{ }^{144} \mathrm{Nd}=\right.$ $0.0100 \pm 0.017)$, the $\mathrm{Nd}$ model ages can represent the main metasomatic events affecting the lithospheric sources beneath the Mongolian regions (veined lithospheric mantle). $\mathrm{T}^{\mathrm{DM}}$ (Table 6) for the whole population (33 samples) fit $992 \pm 119 \mathrm{Ma}$, indicating a Neoproterozoic event ended with the Mushgai Khudag complex $(797 \pm 110 \mathrm{Ma})$. The latter dates are similar to the youngest Os model ages (1.1 and 0.7 - $0.5 \mathrm{Ga}$ ) [42], and may support significant melt extraction from the subcontinental mantle or metasomatic events, suggesting also involvement of the Central Asian Orogenic belt and development of significant juvenile crustal growth.

\section{Acknowledgements}

We acknowledge Professor Yoshihiro Sawada for his support in XRF analyses, Professor Masahide Akasaka for providing and helping in EPMA and XRD analyses, Professor Jun-ichi Kimura for supporting in ICP-MS 
analyses, and also to Mrs. Akasaka for her help in preparing samples for isotope analyses. We also acknowledge A. R. Chakhmouradian, Cheng Xu, Hana Cihlarova, P. Gadas and R. Skoda for the acquisition of analytical data and support. Thank Mr. Kh. Enkhtuvshin and D. Batbold, Yo. Majigsuren for their help in field work.

Finally, we acknowledge for the financial support on Monbusho (Japanese Ministry of Education and Culture) and CEITEC CZ.1.05/1.1.002.0068, Czech Republic.

P.C.C. dedicates this paper to the memory of Enzo Michele Piccirillo.

\section{REFERENCES}

[1] B. A. Baskina, I. K. Volchanskaya, V. I. Kovalenko, et al., "Potassic Alkaline Volcanic-Plutonic Complex of Mushgai Khudag in South Mongolia and Related Mineralization," Sovetskaya Geologiya, No. 4, 1978, pp. 86-99 (in Russian).

[2] V. A. Baskina, I. K. Volchanskaya, V. I. Kovalenko, V. S. Samojlov, N. V. Vladykin, A. V. Goreglad, O. D. Suetenko and V. F. Shuvalov, "The Potassic Alkaline VolcanicPlutonic Massif at Mushugai Khuduk in South Mongolia and Related Mineralization," Sovetskaya Geologiya, Vol. 4, 1978, pp. 86-99 (in Russian).

[3] V. S. Samoilov and V. I. Kovalenko, "Complexes of Alkaline Rocks and Carbonatites in South Mongolia," Nauka, Vol. 35, 1983, p. 196 (in Russian).

[4] D. Batbold, "Mineralogy of the Carbonatite from the Lugiin Gol Alkaline Pluton, South Mongolia," Mongolian Geoscientist, Vol. 8, 1998, p. 37.

[5] Kh. Enkhtuvshin, "A Petrological Study on the Late Mesozoic and Cenozoic Volcanic Rocks of the Mongolian Plateau," Master Thesis, Shimane University, 1995, p. 119.

[6] O. Gerel, B. Munkhtengel, H. Enkhtuvshin and D. Batbold, "Petrology and Geochemistry of the Mushgai Khudag Volcanic-Plutonic Complex," Geology, Vol. 4, 2001, pp. 51-58 (in Monglian).

[7] I. A. Andreeva, V. I. Kovalenko and V. B. Naumov, "Origin, Magma Content, and Genesis of Silicate Magma of Alkaline Carbonatite-Bearing Complex of Mushgai Khudag, South Mongolia," Petrology, Vol. 9, 2001, pp. 563-582 (in Russian).

[8] Q.-R. Meng, "What Drove Late Mesozoic Extension of the Northern China-Mongolia Tract?" Tectonophysics, Vol. 369, No. 3-4, 2003, pp. 155-174. http://dx.doi.org/10.1016/S0040-1951(03)00195-1

[9] J. V. Amory, M. S. Hendrix, M. Lamb, A. M. Keller, G. Badarch and O. Tomurtogoo, "Permian Sedimentation and Tectonics of Southern Mongolia. Implications for a Time-Transgressive Collision with North China," Geological Society of America, Abstracts with Program, Vol. 26, No. 7, 1994, p. 242.

[10] C. M. Han, M. Sun, S. F. Lin, H. L. Chen, Z. L. Li and J. L. Li, "NW China: Implications for the Tectonic Evolution of Central Asia," Journal of Asian Earth Sciences, Vol. 32, No. 2-4, 2008, pp. 102-117. http://dx.doi.org/10.1016/j.jseaes.2007.10.008

[11] J. Kynicky and P. Samec, "Hydrothermally-Metasomatic and Exsolution-Like Mineralization of the Carbonatites from the Selected Localities at Gobi," Mongolian Geoscientist, Vol. 27, 2005, pp. 52-56.

[12] D. Batbold, "Mineralogy of the Carbonatite from the Lugiin Gol Alkaline Pluton, South Mongolia," Master Thesis, Shimane University, Matsue, 1997, p. 210.

[13] V. I. Kovalenko, V. V. Yarmolyuk, I. A. Andreeva, N. A. Ashikhmina, A. M. Kozlovsky, E. A. Kudryashova, V. A. Kuznetsov, E. N. Listratova, D. A. Lykin and A. V. Nikiforov, "Part 2. Magma Types and Their Source in the History of the Earth. Rare Metal Magmatism: Rock Associations, Content and Magma Sources, Geodynamic Environment," M. IGEM RAN, 2006, p. 280.

[14] J. Kynicky, "Petrology of the Carbonatites from the Selected Localities at Gobi," Master Thesis, Masyryk University, Brno, 2002, p. 78.

[15] Japan International Cooperation Agency and Metal Mining Agency of Japan, "Report on the Mineral Exploration in Uudam-Tal Area,” Mongolian People's Republic (Phase I), 1992.

[16] A. Streckeisen, "To Each Plutonic Rock Its Proper Name," Earth Science Reviews, Vol. 12, No. 1, 1976, pp. 1-33. http://dx.doi.org/10.1016/0012-8252(76)90052-0

[17] R. W. Le Maitre, Ed., "A Classification of Igneous Rocks and Glossary of Terms," Oxford, Blackwell, 1989, p. 193.

[18] J. Kynicky, C. Xu, A. R. Chakhmouradian, E. Reguir, H. Cihlářová and M. Brtnický, "REE Mineralization of High Grade REE-Ba-Sr and REE-Mo Deposits in Mongolia and China," Mineralogical Magazine (Goldschmidt Abstracts), Vol. 75, 2011, p. 1260.

[19] J. Kynicky, A. R. Chakhmouradian, C. Xu, M. Vašinová, M. Brtnický and M. Smith, "Origin and Evolution of the Lugiin Gol Carbonatites (Southern Mongolia) and Associated Rare-Earth Mineralization," Ore Geology Reviews, Vol. 53, 2013, in Print.

[20] J. Kynicky, "Primary and Secondary Minerals of Carbonatites of South Mongolia," Mineral, Vol. 11, 2003, pp. 57-61.

[21] J. Kynicky, "Carbonatites of South Mongolia," Dissertation Thesis, Mendel University, Brno, 2006, p. 181.

[22] P. Comin-Chiaramonti, C. B. Gomes, A. Cundari, F. Castorina and P. Censi, "A Review of Carbonatitic Magmatism in the Paraná-Angola-Etendeka (Pan) System," Periodico di Mineralogia Ezio Callegari, Vol. 76, 2007, pp. 25-78.

[23] M. J. Le Bas and R. W. Le Maitre, A. Streckeisen and B. Zanettin, "A Chemical Classification of Volcanic Rocks Based on the Total Alkali-Silica Diagram," Journal of Petrology, Vol. 27, No. 3, 1986, pp. 745-750. http://dx.doi.org/10.1093/petrology/27.3.745

[24] E. A. K. Middlemost, "Naming Materials in the Magma Igneous System," Earth-Science Review, Vol. 37, No. 3-4, 1994, pp. 215-224.

http://dx.doi.org/10.1016/0012-8252(94)90029-9

[25] L. Beccaluva, M. Barbieri, H. Born, P. Brotzu, M. Coltorti, A. Conte, C. Garbarino, C. B. Gomes, G. Macciotta, L. Morbidelli, E. Ruberti, F. Siena and G. Traversa, "Frac- 
tional Crystallization and Liquid Immiscibility Processes in the Alkaline-Carbonatite Complex of Juquiá (São Paulo, Brazil)," Journal of Petrology, Vol. 33, No. 6, 1992, pp. 1371-1404. http://dx.doi.org/10.1093/petrology/33.6.1371

[26] E. Ruberti, F. Castorina, P. Censi, P. Comin-Chiaramonti, C. B. Gomes, P. Antonini and F. Andrade, "The Geochemistry of the Barra do Itapirapuã Carbonatite (Ponta Grossa Arch, Brazil): A Multiple Stockwork," Journal of South America Earth Sciences, Vol. 15, No. 2, 2002, pp. 215-228. http://dx.doi.org/10.1016/S0895-9811(02)00031-7

[27] T. N. Irvine and W. R. A. Baragar, "A Guide to the Chemical Classification of the Common Volcanic Rocks," Canadian Journal of Earth Sciences, Vol. 8, No. 5, 1971, pp. 523-548. http://dx.doi.org/10.1139/e71-055

[28] R. W. Le Maitre, "Some Problems of the Projection of Chemical Data into Mineralogical Classifications," Contributions to Mineralogy and Petrology, Vol. 56, No. 2, 1976, pp. 181-189.

http://dx.doi.org/10.1007/BF00399603

[29] A. Streckeisen, "IUGS Subcommission on the Systematic of Igneous Rocks," Neues Jahrbuch für Mineralogie, Abhandungen, Vol. 143, 1978, pp. 1-14.

[30] G. E. R. Gomes, C. B. Comin-Chiaramonti and P. Hydrothermal, "REE Fluorocarbonatite Mineralization at Barra do Itapirapuã, a Multiple Stockwork Carbonatite, Southern Brazil," Can Mineral, Vol. 46, 2008, pp. 901-914. http://dx.doi.org/10.3749/canmin.46.4.901

[31] S.-S. Sun and W. F. McDonough, "Chemical and Isotopic Systematics of Oceanic Basalts: Implications for Mantle Composition and Processes," In: A. D. Saunders and M. J. Norry, Eds., Magmatism in the Ocean Basinsi Geological Society of London Sp., Vol. 42, 1989, pp. 313-345.

[32] P. Comin-Chiaramonti and C. B. Gomes, Eds., "Mesozoic to Cenozoic Alkaline Magmatism in the Brazilian Platform," Edusp/Fapesp, São Paulo, 2005, p. 757.

[33] S. F. Foley, "Petrological Characterization of the Source Components of Potassic Magmas: Geochemical and Experimental Constraints," Lithos, Vol. 28, No. 3-6, 1992, pp. 187-204.

[34] S. F. Foley, "Vein Plus Wall-Rock Melting Mechanism in the Lithosphere and Origin of Potassic Alkaline Magmas," Lithos, Vol. 28, No. 3-6, 1992, pp. 435-453. http://dx.doi.org/10.1016/0024-4937(92)90018-T

[35] W. V. Boynton, "Cosmochemistry of the Rare Earth Elements: Meteorite Studies," In: P. Henderson, Ed., Rare Earth Element Geochemistry, Elsevier, Amsterdam, 1984, pp. 63-114. http://dx.doi.org/10.1016/B978-0-444-42148-7.50008-3

[36] B. Munkhtsengel and S. Iizumi, "Rb-Sr Geochronology and $\mathrm{Sr}-\mathrm{Nd}$ Isotope Systematics of the Mushgai Khudag Syenite and Bayan Khoshuu Monzonite in South Mongolia," Mongolian Geoscientist, Vol. 14, 1999, pp. 14-16.

[37] B. Munkhtsengel and S. Iizumi, "Petrology and Geochemistry of the Lugiin Gol Nepheline Syenite Complex in the Gobi-Tien Shan Fold Belt, Southern Mongolia: A Post-Collisional Potassic Magmatism," Mongolian Geoscientist, Vol. 14, 1999, pp. 12-14.

[38] A. Zindler and S. Hart, "Chemical Geodynamics," Annual
Review of Earth and Planetary Sciences, Vol. 14, 1986, pp. 493-471.

http://dx.doi.org/10.1146/annurev.ea.14.050186.002425

[39] G. Faure, "Principles of Isotope Geology," 2nd Edition, Wiley, New York, 1986.

[40] D. J. De Paolo, "Trace Element and Isotopic Effects of Combined Wallrock Assimilation and Fractional Crystallization," Earth and Planetary Science Letters, Vol. 53, No. 2, 1981, pp. 189-202. http://dx.doi.org/10.1016/0012-821X(81)90153-9

[41] V. I. Kovalenko, V. V. Yarmolyuk, V. P. Kovach, A. B. Kotov, I. K. Kozakov, E. B. Salnikova and A. M. Larin, "Isotope Provinces, Mechanisms of Generation and Sources of the Continental Crust in the Central Asian Mobile Belt: Geological and Isotopic Evidence," Journal of Asian Earth Sciences, Vol. 23, No. 5, 2004, pp. 605627. http://dx.doi.org/10.1016/S1367-9120(03)00130-5

[42] L.-K. Wang, S. O’Reilly, V. Kovach, W. L. Griffin, N. J. Pearson, V. Yarmolyuk, M. I. Kuzmin, C.-J. Chieh, J. G. Shellnutt and Y. Izuka, "Microcontinents among the Accretionary Complexes of the Central Asia Orogenic Belt: In Situ Re-Os Evidence," Journal of Asian Earth Sciences, Vol. 62, 2013, pp. 37-50. http://dx.doi.org/10.1016/j.jseaes.2011.09.016

[43] A. Zindler, E. Jagoutz and S. Goldstein, "Nd, Sr and $\mathrm{Pb}$ Isotopic Systematics in a Three-Component Mantle: A New Perspective," Nature, Vol. 298, 1982, pp. 519- 523.

[44] S. R. Hart, D. C. Gerlach and W. M. White, "A Possible New Sr-Nd-Pb Mantle Array and Consequences for Mantle Mixing," Geochimica et Cosmochimica Acta, Vol. 50, No. 7, 1986, pp. 1551-1557.

[45] S. R. Hart, "Heterogeneous Mantle Domains; Signatures, Genesis and Mixing Chronologies," Earth and Planetary Science Letters, Vol. 90, No. 3, 1988, pp. 273-296. http://dx.doi.org/10.1016/0012-821X(88)90131-8

[46] B. L. Weaver, "The Origin of Ocean Island End-Member Compositions: Trace Element and Isotopic Constraints," Earth and Planetary Science Letters, Vol. 104, No. 2-4, 1991, pp. 381-397. http://dx.doi.org/10.1016/0012-821X(91)90217-6

[47] M. A. Lamb and G. Badarch, "Paleozoic Sedimentary Basins and Volcanic-Arc Systems of Southern Mongolia: New Stratigraphic and Sedimentologic Constraints," International Geology Review, Vol. 39, No. 6, 1997, pp. 542-576. http://dx.doi.org/10.1080/00206819709465288

[48] U. Wiechert, D. A. Ionov and K. H. Wedepohl, "Spinel Peridotite Xenoliths from the Atsagir-Dush Volcano, Dariganga Lava Plateau, Mongolia: A Record of Partial Melting and Cryptic Metasomatism in the Upper Mantle,' Contributions to Mineralogy and Petrology, Vol. 126, No. 4, 1997, pp. 345-364. http://dx.doi.org/10.1007/s004100050255

[49] D. Burianek, P. Hanzl, V. Erban, H. Gilikova and K. Bolormaa, "The Early Cretaceous Volcanic Activity in the Western Part of the Gobi-Altai Rift (Shiliing Nuruu, SW Mongolia)," Journal of Geosciences, Vol. 53, 2008, pp. 167-180.

[50] A. Peccerillo, "Potassic and Ultraotassic Rocks: Compositional Characteristics, Petrogenesis and Geologic Significance," Episodes, Vol. 15, 1992, pp. 243-251. 